University of Louisville

ThinkIR: The University of Louisville's Institutional Repository

Electronic Theses and Dissertations

8-2014

\title{
The impact of preconception maternal stress on fecundability and adverse pregnancy outcomes.
}

Shekufe Akhter

University of Louisville

Follow this and additional works at: https://ir.library.louisville.edu/etd

Part of the Epidemiology Commons

\section{Recommended Citation}

Akhter, Shekufe, "The impact of preconception maternal stress on fecundability and adverse pregnancy outcomes." (2014). Electronic Theses and Dissertations. Paper 21.

https://doi.org/10.18297/etd/21

This Master's Thesis is brought to you for free and open access by ThinkIR: The University of Louisville's Institutional Repository. It has been accepted for inclusion in Electronic Theses and Dissertations by an authorized administrator of ThinkIR: The University of Louisville's Institutional Repository. This title appears here courtesy of the author, who has retained all other copyrights. For more information, please contact thinkir@louisville.edu. 


\title{
THE IMPACT OF PRECONCEPTION \\ MATERNAL STRESS ON FECUNDABILITY \\ AND ADVERSE PREGNANCY OUTCOMES
}

\author{
Shekufe Akhter \\ B.S, University of Louisville, 2012

\begin{abstract}
A Thesis
Submitted to the Faculty of the

School of Public Health and Information Science at the University of Louisville

In Fulfillment of the Requirements
\end{abstract}

For the Degree of

Master of Science

Department of Epidemiology and Population Health

University of Louisville

Louisville, KY

August 2014 



\title{
THE IMPACT OF PRECONCEPTION MATERNAL STRESS ON FECUNDABILITY AND ADVERSE PREGNANCY OUTCOMES
}

\section{By}

Shekufe Akhter

B.S., University of Louisville, 2012

A Thesis approved on

July 22, 2014

by the following Thesis Committee

\author{
Thesis Committee Director \\ Dr. Kira Taylor, Ph.D
}

Second Committee Member

Dr. Richard Kerber, Ph.D

Third Committee Member

Dr. Maiying Kong, Ph.D 


\title{
DEDICATION
}

\author{
This thesis is dedicated to my loving parents \\ Dr. Rafiqul Alam and Mrs. Dalia Akther \\ for their endless support, prayers, and patience. \\ It is because of their sacrifice, faith, and undivided love \\ that I have reached this platform and have become \\ stronger in my life and career.
}

Thank you Ammu and Abbu 


\section{ACKNOWLEDGMENTS}

First and foremost, I give thanks to God Almighty for being my backbone throughout my life and for every chance He has given me.

I am forever in debt to the amount of knowledge, guidance, and patience that Dr.T has given me. Thank you for dotting my $\mathrm{i}^{\mathrm{ee}} \mathrm{s}$ and crossing my $\mathrm{t}^{\mathrm{ee}} \mathrm{s}$ throughout every step. I thank Dr. Kerber for inspiring me to experience a variety of statistical methods and analysis plans. To Dr. Kong for helping me come to peace with the complexity of longitudinal data. Thank you to the entirety of my amazing committee and professors - I have achieved today only because of you and I truly appreciate each of you for sharing your knowledge with me and giving me the opportunity of learning beside you.

I honestly could not have found better friends in this world. I have handpicked all of you to be my lifelong companions and I am honored to be a part of your life. I appreciate each of you for your prayers, laughs, and the persistent push and motivation I need to keep climbing the ladder.

Thank you to each of my beautifully strong sisters. No matter how much we bicker and argue, I need you guys in every day of my life for I never stop learning from you guys. I could not have asked for better siblings.

Lastly, I thank you my love for being in my life. Since the beginning, you believed in my vision and never lost your faith in me. Thank you for being the reason I smile every day, for teaching me patience and perseverance, and for being my strength. 


\section{ABSTRACT \\ THE IMPACT OF PRECONCEPTION MATERNAL STRESS ON FECUNDABILITY AND PREGNANCY OUTCOMES}

Shekufe Akhter

July 22, 2014

It has been commonly hypothesized (and widely believed) that maternal stress either prior to or during pregnancy can adversely affect fertility and pregnancy outcomes. However, surprisingly few epidemiologic studies have rigorously tested these hypotheses. The current study evaluated the effects of pre-conception self-reported stress on fecundability and spontaneous abortion. The study population was derived from the Mount Sinai Study of Woman Office Workers with 487 women included. Women recorded stress (scale from 1 to 4 ) and covariate information in a daily diary for 12 cycles or until pregnant. Results indicated a significantly increased risk of spontaneous abortion for women with higher levels of self-reported stress during the cycle of conception, and reduced fecundability when high stress occurred during the ovulatory window. This study reinforces the need for ameliorating stress in the aspiring and expecting mother. Future studies may examine effects of stress-related biomarkers and genetic polymorphisms on pregnancy outcomes. 


\section{TABLE OF CONTENTS}

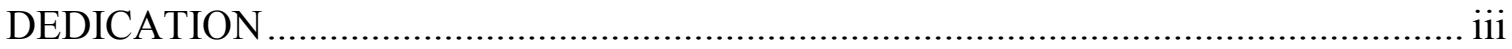

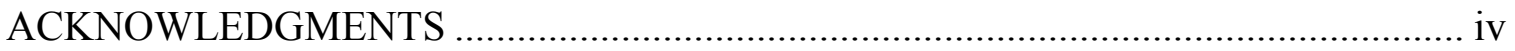

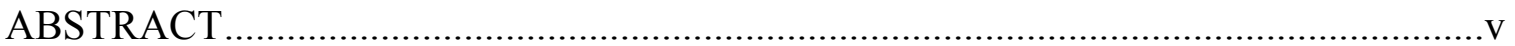







Biological background of stress during pregnancy ………………………………………. 1

Biological mechanisms behind stress-activated reproductive failure ………………………... 2



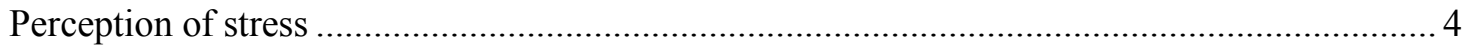

Epidemiological studies of stress and fecundability .......................................................... 5

Prospective studies of stress and fecundability ................................................................. 6

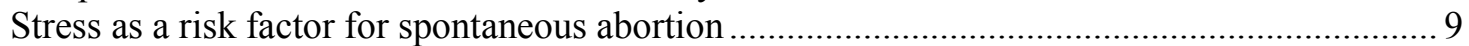

Studies examining self-reported stress and spontaneous abortion .......................................... 10

Studies examining biomarkers of stress and spontaneous abortion ………………………..... 11

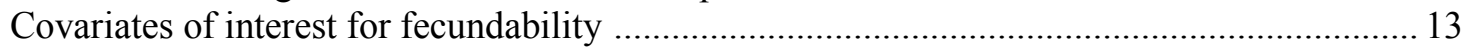

Covariates of interest for spontaneous abortion ………….............................................. 14

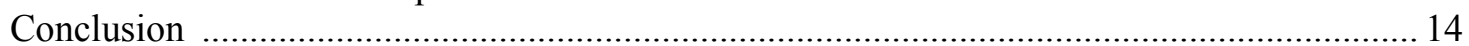

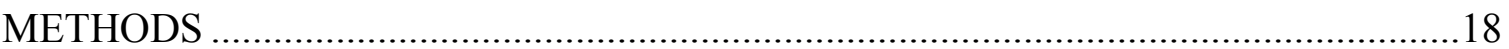

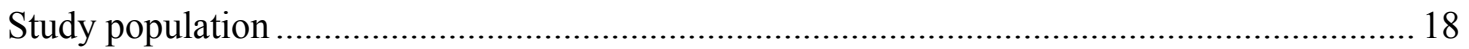

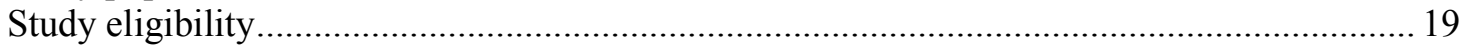

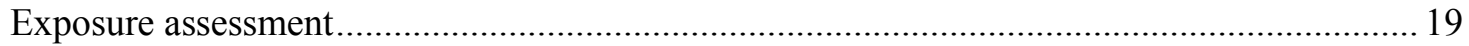

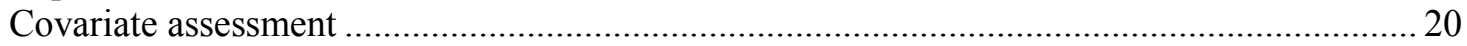

Fecundability and spontaneous abortion............................................................................ 21

Statistical analysis for fecundability ............................................................................. 21

Evaluation and selection of covariates...........................................................................22

Statistical analysis for risk of spontaneous abortion ......................................................... 23







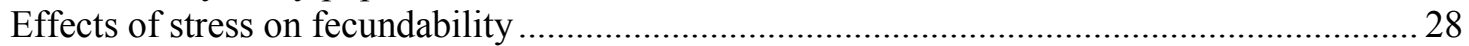



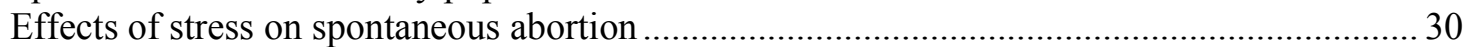




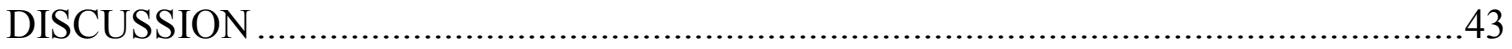

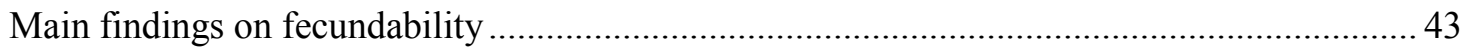

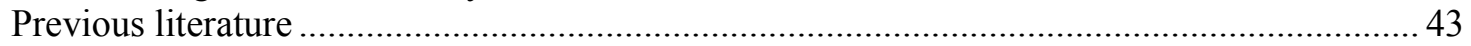

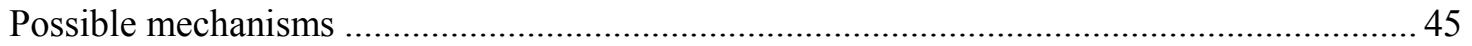

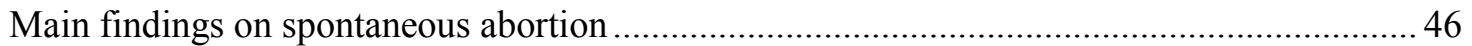

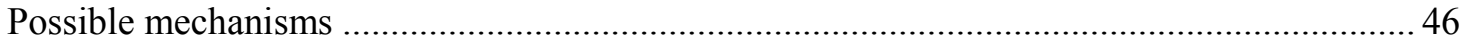

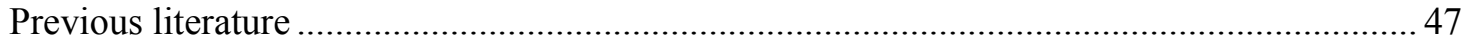



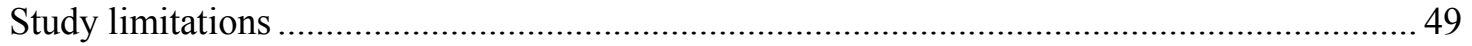

CONCLUSION

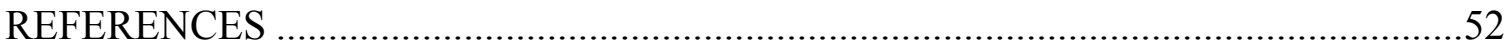

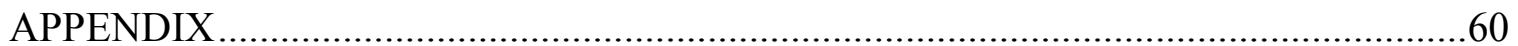






\section{LIST OF TABLES}



Epidemiological studies examining self-reported stress and fecundability ................16 Epidemiological studies examining self-reported stress and spontaneous abortion ....17

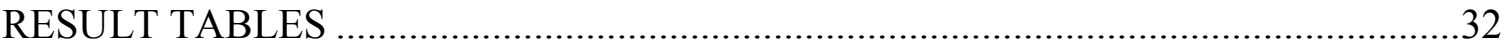

Characteristics of Study Participants with Self-Reported Stress and Covariates in the Mount Sinai Study of Women Office Workers

Characteristics of Pregnant and Non-pregnant Women in the Mount Sinai Study of

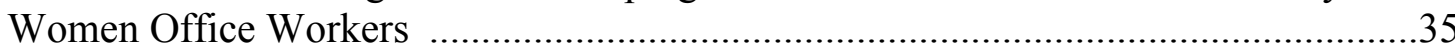

Characteristics of Pregnant Women in the Mount Sinai Study of Women Office

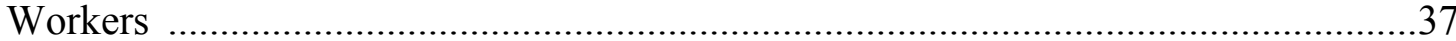

Multivariable model for fecundability of first pregnancies.......................................39

Multivariable model for fecundability for first pregnancies (relative stress)................40

Multivariable model for spontaneous abortion for first pregnancies ..........................41

Multivariable model for spontaneous abortion for first pregnancies (relative stress)...42 


\section{LIST OF FIGURES}

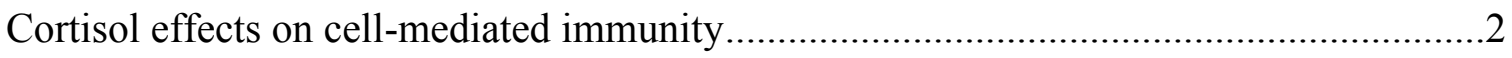



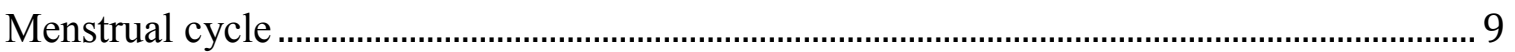

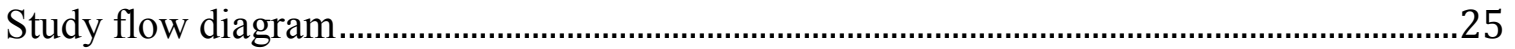

Directed acyclic graph: Stress and fecundability ...........................................................26

Directed acyclic graph: Stress and spontaneous abortion......................................................26 


\section{INTRODUCTION}

Biological background of stress during pregnancy

In simple terms, stress can be defined as any mental, psychological, or physiological response to an event that increases mental tension (Catherino 2011). However from a biological stance, stress is considered a rise in the secretion of hormones due to the stimulation of the neuroendocrine hypothalamo-pituitary-adrenal (HPA) axis (Parker et al. 2010). In response to stressful situations, the corticotropin-releasing hormone $(\mathrm{CRH})$ from the hypothalamus stimulates adrenocorticotropic hormone $(\mathrm{ACTH})$ from the pituitary gland, which then stimulates the adrenal cortex to release specific amounts of glucocorticoids (e.g. cortisol) (Pruessner et al. 1997, Gatti et al. 2009). During pregnancy the new environment is characterized through the major maternal tissues and increased HPA axis function, but if glucocorticoids continue to be secreted in high concentrations, it can be detrimental to the developing endometrium (Nakamura et al. 2008).

Along with the HPA axis, a stress response can be triggered by the hypothalamopituitary-gonadal (HPG) axis. All major endocrine systems function together to regulate the immune system and create a protective environment necessary for proper establishment and regulation of pregnancy (Parker et al. 2010). Therefore the mother's response to changes in hormonal stress plays a pivotal role in the overall maintenance of a tolerogenic immune environment. But there still exists a great deal of controversy regarding the etiology underlying a stress trigger and risk of spontaneous abortion. 


\section{Biological mechanisms behind stress-activated reproductive failure}

One theory of stress-activated reproductive failure scrutinizes the suitable equilibrium between the neuroendocrine and immune systems. Pro-inflammatory cytokines are released from immune cells in response to tissue injury or infection and can cause systemic inflammation. After activating the sympathetic nervous system, cytokines activate the HPA axis while temporarily suppressing the HPG axis(Goodman 2008). This can create a hypoinflammatory response that will only increase if the stressor is prolonged.

In normal cases of stress, glucocorticoids bind to NFkappaB (cytokine) preventing it from entering the nucleus and activating target genes. This will increase immune function back to normal; however, excessive stress, i.e. chronic stress, disrupts the positive feedback loop of pro-inflammatory cytokines. Chronic stress occurs for an elongated period of time and can be physiologically debilitating (Baum et al. 1999).

\begin{abstract}
and cortisol acts directly on B cells to decrease
Cortisol decreases pro -inflammatory cytokines, which play a role in increasing the number of Bcell and T-cells in cell-mediated immunity (Fig. $\left.1^{*}\right)$
\end{abstract}

antibody proliferation and induce cell apoptosis. Therefore, chronic stress will overshoot the decrease in immune function leading to immune suppression, as shown in Fig.2.

\footnotetext{
*Goodman, M. H. (2008). Basic Medical Endocrinology, Academic Press.
}

Figure 1: Cortisol effects on cell-mediated immunity $^{1}$

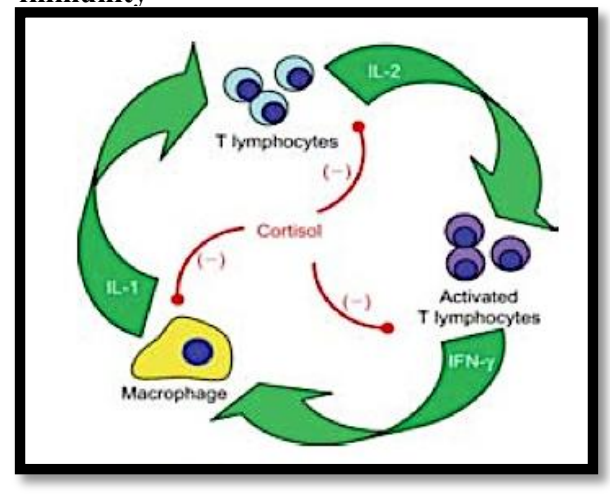

Cortisol inhibits proliferation of activated T cells by interfering with secretion of cytokines. IL-1 = interleukin-1; IL-2 = interleukin II; IFN- $\gamma=$ interferon- $\gamma$. 
Figure 2: Immune function across variation of stress 1

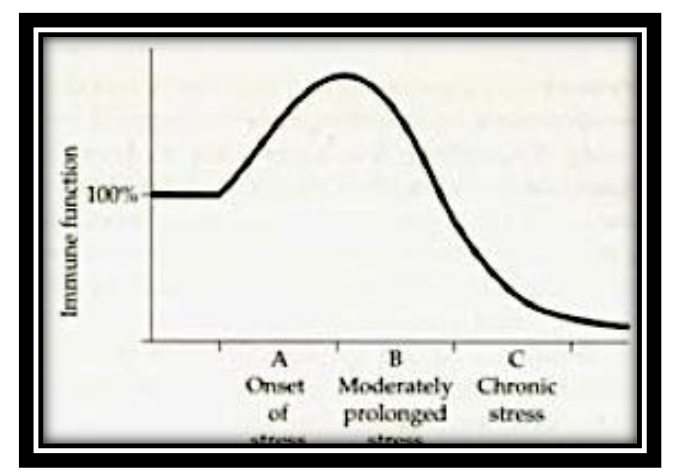

A. Moderate increase in immune function B. Immune function decreased back to baseline C. Prolonged stress overshoots decreaseleading to immune suppression
The process of implantation is a form of

uterine inflammation and intracellular cytokines such as uterine NFkappaB are critical during implantation (Nakamura et al. 2004). However, if glucocorticoids are working to suppress NFkappaB and the local inflammation, then they are indirectly compromising the process of implantation (Parker et al. 2010). Moreover, the

timing of glucocorticoid release and location of its release are of critical importance in the maintenance of pregnancy. During the luteal phase, progesterone levels elevate in order to prepare the endometrium for embryonic development (Wang et al. 2004). Yet if high levels of glucocorticoids are circulating in the endometrium, it can delay the onset of ovulation, thereby shortening the luteal phase (Nakamura et al. 2008) and progesterone availability necessary for successful implantation (Magiakou et al. 1997, Arck et al. 2008). By interrupting the luteal phase, elevated levels of circulating glucocorticoids may be preventing proper implantation (Nepomnaschy et al. 2004).

\section{Biomarkers of stress}

Biomarkers are biological measurements from bodily fluids such as blood or urine that are indicative of biological or pathogenic processes. Numerous biomarkers of stress in association with fertility have been ascertained including $\mathrm{CRH}$ concentrations (Arck et al. 2008), salivary $\alpha$-amylase (Nierop et al. 2006, Louis et al. 2011), and cortisol

(Nepomnaschy et al. 2006, Salacz et al. 2012). 
Salivary $\alpha$-amylase is the principal protein released in response to sympathetic nervous system activation after a stress trigger that increases the amount of glucocorticoids in the blood (Louis et al. 2011). Many studies have found promising results using salivary $\alpha$-amylase, but timing of sample collection must be considered due to the variation of stress levels during circadian rhythms (Louis et al. 2011).

Cortisol is a glucocorticoid released from the adrenal cortex in response to a stress trigger from the ACTH. Cortisoles primary functions include regulating blood pressure and blood sugar levels, and suppressing the immune system. Elevated levels of cortisol in the system for a prolonged period reduces antibody production and kills vital immune cells, thereby making the body more susceptible to infections (Torpy et al. 1996, Nepomnaschy et al. 2006). In addition, cortisol suppresses secretion of estrogen, testosterone, and luteinizing hormone thereby potentially interrupting fertility (Nepomnaschy et al. 2006, Nakamura et al. 2008).

\section{Perception of Stress}

Personality tests are the most popular approach for measuring relationships between stress responses and pregnancy outcomes. Some examples include Personality Stress Questionnaire (Arck et al. 2008), Perceived Stress Scale (PSS), and the Prenatal Social Environment Inventory (PSEI) (Nelson et al. 2003), but the State-Trait Anxiety Inventory (STAI) (Takai et al. 2004, Lynch et al. 2012) is most commonly used. Psychological measures are considered more subjective than the previously mentioned physiological measures and have recently become more common with many studies finding significant associations with pregnancy outcome (Nelson et al. 2003, Arck et al. 2008). 
Increasing attention has been given to correlation between self-reported psychosocial stress and measured biomarkers. Perceived chronic stress has been shown to be associated with higher salivary cortisol levels upon awakening in some studies (Schulz et al. 1998, Wust et al. 2000). Yet in a study by Takai et al. (2004), when biomarkers were tested with reported stress measures (STAI), there was a significant correlation with $\alpha$-amylase $(\mathrm{r}=0.535, \mathrm{p}$-value $<0.01)$ but not with cortisol $(\mathrm{r}=0.220, \mathrm{p}$-value $>0.05)$. This finding was consistent with others that examined the same relationship (Bosch et al. 1996, Skosnik et al. 2000, Nelson et al. 2003). On the other hand, a prospective study by Lynch et al. (2012) followed 339 women for six cycles to examine the correlation between scores on two types of psychosocial questionnaires (STAI and PSS) and concurrently measured levels of salivary $\alpha$-amylase and cortisol and found no correlation with either test. Nevertheless, this could have been partly due to timing of data collection during the follicular phase of the cycle and their short time period of six cycles. Due to these contradictory findings, it is difficult to determine which method of stress measurement, psychosocial tests or biomarkers, is best in terms of accuracy.

\section{Epidemiologicalstudies of stress and fecundability}

The belief that maternal stress prior to or during pregnancy can have adverse effects on fertility and pregnancy outcomes has received much attention in recent years partly due to the rising number of infertility cases. However, the few epidemiologic studies that have rigorously tested these hypotheses are highly contradictory with several agreeing that high stress significantly reduces fertility (Hjollund et al. 1999, Maconochie et al. 2007, Nakamura et al. 2008, Louis et al. 2011) while other studies have found no 
associations (Anderheim et al. 2005, Lynch et al. 2012).

Stress has been suspected to affect reproductive failure through anovulation (Bonen 1994), implantation failure (Symonds et al. 2007), and dysregulation of the placenta (Malassine et al. 2002, Nakamura et al. 2008). The idea that stress decreases fertility can be largely attributed to studies reporting natural conception by infertile couples soon after the adoption of a child (Rock et al. 1965, Weir et al. 1966, Mai 1971)and, more recently, increased probability of pregnancy among in vitro fertilization (IVF) patients undergoing stress reduction interventions (Domar et al. 2000, KlonoffCohen et al. 2001, de Liz et al. 2005). Domar et al. (2000) found a higher pregnancy rate among women undergoing cognitive-behavioral therapy (P-value 0.001) or standard support groups (P-value .0146) compared to the control group and more recently demonstrated that mind-body interventions resulted in increased pregnancy rates among couples undergoing IVF (Domar et al. 2011). These studies imply that stress reduction behavioral therapies can reduce the impact of stress on conception for infertile couples thereby highlighting stress as a risk factor.

\section{Prospective studies of stress and fecundability}

Despite literature demonstrating a relationship between stress and fertility only two prospective epidemiologic studies have rigorously investigated the hypothesis behind stress and fecundability, the LIFE study (Lynch et al. 2012, Lynch et al. 2014) and the Oxford Conception Study (Louis et al. 2011). Buck-Louis et al. (2011) found that a higher salivary concentration of $\alpha$-amylase was associated with significantly reduced probability of conception among 274 women attempting pregnancy. Women were asked to collect saliva samples on day 6 of each cycle, use fertility monitors to determine the 
day of ovulation, and to test for pregnancy on the days after missed menses. Along with assessing fecundity by time to pregnancy analysis, they also evaluated probability of pregnancy during the fertile window using estimates from Bayesian modeling techniques. The fertile window was defined as originating five days before estimated day of ovulation through the day after ovulation (Louis et al. 2011). Results indicated no association with salivary cortisol but there was a negative association between salivary $\alpha$ amylase concentrations and fecundity (fecundity odds ratio (FOR) 0.85 ; 95\% CI 0.67, 1.09) after adjustment for associated covariates with the highest day-specific conception probability on the day before ovulation followed by day 1 after ovulation. When a correlation test was conducted between salivary amylase and salivary cortisol, there was no significant association and this was consistent with previous findings (Nater et al. 2005).

Although Lynch et al. (2012) found no association between psychosocial measures of stress and fecundity, a recent study extending their previous work examined the association between salivary biomarkers of stress and infertility(Lynch et al. 2014). Approximately 401 women were followed for 12 months or until pregnancy occurred. They collected first-morning saliva samples at two different time points: the morning after enrollment and the morning of their first menses in the study. Daily diaries were used to collect covariate information including menstrual cycle characteristics, intercourse frequency, smoking, caffeinated and alcoholic beverage consumption, and use of contraception. Results indicate lower fecundity for women with the highest tertile of $\alpha$ amylase (FOR 0.71; 95\% CI 0.51-1.00), adjusting for maternal age, difference in age between male and female, income of female, race of female, smoking, caffeine, and 
alcohol consumption (Lynch et al. 2014). This decreased fecundity translates into a 2-fold increased risk of infertility among these women [relative risk (RR) 2.07 ; 95\% CI 1.044.11). Consistent with past studies, no association was found between salivary cortisol and fecundability (Louis et al. 2011).

One prospective study found a significant association between self-reported measures of stress and fecundability. Hjollund et al. (1999) followed 430 couples until pregnancy or six cycles of follow-up. Couples were asked to complete a questionnaire for stress levels on day 21 of each cycle. If the women discovered the attempt to become pregnant was successful or not prior to completing the questionnaire, this could lead to bias. Therefore to avoid a false association, couples were instructed to complete the questionnaire on a specific day of the cycle, i.e day 21 , before they took the pregnancy test. Cycles with higher distress scores had a lower probability of pregnancy than cycles with lower scores (adjusted OR 0.6; 95\% CI 0.4-1.0), with a stronger effect among women with longer menstrual cycles ( $\geq 35$ days, OR $0.1 ; 95 \%$.01- 0.4 ). This finding suggests that perhaps menstrual cycle length could be a modifier in the causal pathway between psychosocial stress and fertility.

Another important point about the study by Hjollund et al. (1999) is their timing of measuring stress during the luteal phase rather than the follicular phase as chosen by Lynch et al. (2012). During the follicular phase, the body is preparing for the growth and maturation of an ovarian follicle. The luteal phase is the period after the day of ovulation and occurrence of pregnancy or 2 weeks before menses begin again and it is during this window of time that implantation ensues (Ghanem et al. 2009, Razieh et al. 2009). The day of ovulation is when the mature follicle ruptures and is capable of becoming 
fertilized if a sperm is successful. But the day of ovulation does not necessarily belong to any one phase rather it is between both the follicular and luteal phase, marked by a surge of luteinizing hormone (see Fig. $3^{\dagger}$ ). Therefore, it could be difficult to determine which time

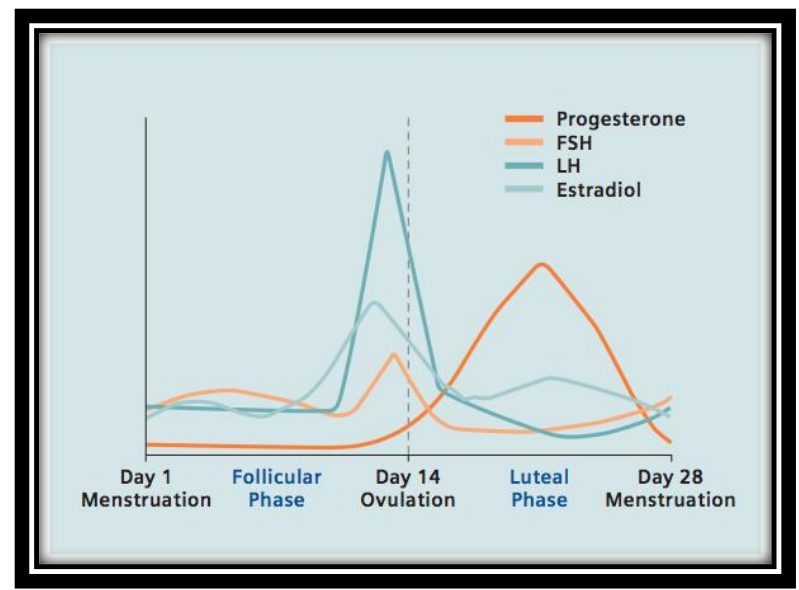

period is most appropriate for capturing

The large spike in luteinizing hormone marks the day of ovulation located between the follicular and luteal phase stress data. If stress affects the process of ovulation or conception, then stress data from the follicular phase would be more relevant; rather if stress affects implantation, then the luteal phase is more relevant. This could explain the discrepancy in literature and therefore, it would be better to obtain data during both the follicular and luteal phase.

\section{Stress as a Risk Factor for Spontaneous Abortion}

Once proper implantation and conception are achieved, there is still a possibility that high stress could interfere in various phases across the pregnancy term. High stress perception could be a risk factor for preterm birth, low birth weight, and spontaneous abortion (Nakamura et al. 2008). Spontaneous abortion is the most common adverse pregnancy outcome, affecting at least 1 out of every 3 pregnant women (Wilcox et al. 1988, Wainstock et al. 2013). It is defined as the spontaneous loss of a fetus $<20$ weeks of gestation, with majority occurring before 7 weeks of pregnancy(Wainstock et al.

\footnotetext{
†Siemens Healthcare Diagnostics (2010)."Hormonal Levels During the Early Follicular Phase of the Menstrual Cycle". USA
} 
2013). Although research has shown that most cases of early spontaneous abortions are caused by genetic or chromosomal abnormalities (50-60\%), much of the etiology behind this pregnancy outcome among embryos without chromosomal abnormalities is not well established (Stern et al. 1996, Schmidt-Sarosi et al. 1998). Nevertheless, early research has shown that common risk factors are smoking, older maternal age (over 33 years), nutritional deficiencies, genital herpes, and endometriosis (Cramer et al. 2000, Arck et al. 2008).

\section{Studies examining self-reported stress and spontaneous abortion}

One prospective study by Hjollund et al. (2000) examined whether self-reported daily measures of physical strain increased the risk of pregnancy loss. This is the earliest study to date to use daily diaries of self-reported stress to assess stress exposure. Out of 181 pregnancies there were 51 reported spontaneous abortions, 19 clinically diagnosed and 32 subclinical pregnancies detected by hCG analysis. Women who reported a higher physical strain than average during the luteal phase at day 6-9 after the estimated day of ovulation had a higher risk ratio of spontaneous abortion compared to those with a lower physical strain scores (adjusted risk ratio (RR) 2.5; 95\% CI $1.3-4.6$ ). The earliest

detectable spontaneous abortion took place after 5 days $\left(26^{\text {th }}\right.$ day of gestation) but the effect size was stronger for pregnancies that lasted at least 5 weeks $(\mathrm{RR}=1.4$; $95 \% \mathrm{CI}$ 0.63.4 and $\mathrm{RR}=4.8 ; 95 \% \mathrm{CI} 2.0-11.4$, respectively). It is during this time period the placenta develops in structure and function (Malassine et al. 2002) and therefore, embryos may be particularly susceptible to maternal changes until the placenta matures.

In a case-control study of 603 women in the UK, numerous exposures of stress were assessed along with various covariates. Results indicated that women who reported 
feeling happy, relaxed, or in control had a $60 \%$ reduction in risk of spontaneous abortion compared to women feeling anxious, overwhelmed, or depressed (OR 0.41; 95\% CI $0.34-$ 0.49 and OR 2.47; 95\% CI 2.02-3.02, respectively) (Maconochie et al. 2007). An increasing trend in odds of miscarriage with increasing number of stressful or traumatic events was observed. Among the significant covariates included in the adjusted model were maternal age, low body mass index (BMI), feeling stressed, alcohol consumption, assisted conception, and previous miscarriage. Moreover paternal age ( $\geq 45$ years) had a significant association with spontaneous abortion (OR=1.63; 95\% CI 1.08-2.47).

\section{Studies examining biomarkers of stress and spontaneous abortion}

In a cohort of 864 women, one prospective study evaluated possible risk factors for spontaneous abortions through ascertainment of serum samples for progesterone and $\mathrm{CRH}$ concentrations as well as using psychosocial questionnaires to measure external sources of stress(Arck et al. 2008). Across all pregnancies, high levels of self-reported stress were not significantly associated with spontaneous abortions. However for women who had a spontaneous abortion, there was a significantly higher perception of stress (as reported by questionnaires) in comparison to women with normal pregnancies (median 40.0 versus 33.3 , respectively, P-value 0.024 ) in the early gestational group (4-7 weeks, $\mathrm{N}=232$ )(Arck et al. 2008). This finding was further substantiated by a significant increase in serum CRH concentration in women who had a spontaneous abortion compared to women with a progressively normal pregnancy (Arck et al. 2008). In addition, a significant association was found between low progesterone levels ( $\leq 12 \mathrm{ng} / \mathrm{ml})$ and an increased risk of spontaneous abortion in the early gestational group (OR $0.51 ; 95 \% \mathrm{CI}$ $0.28-0.91$ ), and after adjusting for BMI and maternal age the risk was greatly elevated 
(OR 7.1; 95\% CI 2.8 - 17.9) (Arck et al. 2008). High concentrations of CRH and glucocorticoids can have an adverse affect on vital progesterone concentrations and on the fragile uterine environment required for a successful implantation (Magiakou et al. 1997, Nakamura et al. 2008).

Another prospective study by Nepomnaschy et al. (2006) examined maternal stress via urinary cortisol levels 3 weeks post conception and its association with miscarriages. Sixty-one women were instructed to collect first morning urine samples every other day for a total of three collections a week during the luteal phase of the menstrual cycle. To account for variation within and between individuals, cortisol samples were standardized with respect to the woman"s baseline cortisol level. If the standardized cortisol level in the first 3 weeks post conception were equal to the woman's baseline level, pregnancies were classified as exposed to „,nomal cortisol“. On the other hand, if standardized cortisol levels 3 weeks post conception were higher than the woman"s baseline cortisol levels, pregnancies were classified as exposed to „high cortisole $^{e e}$. Results indicate that women with increased cortisol levels during the implantation were 2.7 times (95\% CI 1.2 - 6.2) more likely to have spontaneous abortions than those with normal cortisol levels.

A cohort study in Germany found a significant association between exposure to life-threatening rocket alarms and spontaneous abortions with an odds ratio of 1.59 (95\% CI 1.2-2.2) (Wainstock et al. 2013). Pregnant women who were exposed to these rocket alarms had a higher rate of spontaneous abortions than those who were unexposed $(6.9 \%$ vs. $4.7 \%$; OR=1.29, $95 \%$ CI 1.17-2.2). These studies examined different exposures of stress pre-conceptionally and during pregnancy and found significant associations with spontaneous abortion. 


\section{Covariates of interest for fecundability}

The pathway to successful conception may be affected by a variety of factors. Unquestionably, pregnancy intention and intercourse frequency increases fertility (Louis et al. 2011, Taylor et al. 2011, Lynch et al. 2014). However, risk factors that have shown to decrease fecundability include higher maternal age, higher BMI, race, and alcohol consumption (Jensen et al. 1998, Hjollund et al. 1999, Lynch et al. 2014).Taylor et al. (2011) found a dose-response effect with a 30\% reduction in fecundability for those who intake $<1$ drink per day and a 50\% reduction for those who took $\geq 1$ drinks per day (FOR $=0.50 ; 95 \%$ CI $0.28-0.89)($ Taylor et al. 2011).

For a couple of behavioral factors, i.e. smoking and caffeine consumption, there still remains a decent amount of controversy on the risk of infertility. Jensen et al. (1998) found reduced fecundability for women who smoked and were exposed to smoking in utero compared to unexposed nonsmokers ( $\mathrm{FOR}=0.53 ; 95 \% \mathrm{CI} 0.31-0.91)$. On the other hand, Buck Louis et al. (2011) found no association between smoking and fecundability. Taylor et al. (2011) did not find any significant association with regards to caffeine consumption; however smoking reduced fecundability but only for slow acetylators(Taylor et al. 2011).The effect of smoking on fecundability may depend on the mother"s ability to metabolize cigarette smoke, due to genetic polymorphisms in enzymes such as NAT2 (Taylor et al. 2011); this could explain the mixed results of smoking and fecundability across studies. Reports on the effects of particular behavioral covariates and fecundability vary by study, and the individual effect estimates are likely affected by unmeasured confounders and effect modifiers. 


\section{Covariates of interest for spontaneous abortion}

There exist a number of well-established risk factors that increase spontaneous abortion including recurrent miscarriage, low BMI, and infertility (Stern et al. 1996, Cramer et al. 2000, Hjollund et al. 2000, Sugiura-Ogasawara et al. 2002, Maconochie et al. 2007, Arck et al. 2008). Among social and behavioral factors, alcohol consumption, smoking, and caffeine intake (Rasch 2003, Nakamura et al. 2008)may have some association with risk of spontaneous abortion, but the interaction among these risk factors still remains very complex and controversial.

Maternal age is a complex factor, and the distribution may be bimodal, with higher risk of SA occurring for both younger (Rasch 2003) and older mothers (Maconochie et al. 2007, Arck et al. 2008). Arck et al. (2008) found the risk of spontaneous abortion to increase for those women with lower progesterone levels and higher age $(\mathrm{OR}=7.13 ; 95 \% \mathrm{CI} 1.96-25.93)$, and the risk increased two-fold after adjusting for $\mathrm{BMI}(\mathrm{OR}=14.15 ; 95 \% \mathrm{CI} 2.81-71.21)$. This finding was consistent with earlier studies (Maconochie et al. 2007, Arck et al. 2008) while others found an association in the opposite direction with younger women having a higher risk of spontaneous abortion $(\mathrm{OR}=3.53 ; 95 \%$ CI 1.34-9.29) (Rasch 2003).

\section{Conclusion}

It has been commonly hypothesized (and widely believed) that maternal stress either prior to or during pregnancy can adversely affect fertility and pregnancy outcomes. There exist some studies supporting an association between either self-reported stress or 
biomarkers of stress and poor fertility outcomes, while others refute such an association. However, surprisingly few epidemiologic studies have rigorously tested these hypotheses. More research is clearly needed to quantify the effects of perceived stress on fertility and pregnancy outcomes. To address this question, the objective of this study is to examine the association between self-reported stress, fecundability, and adverse pregnancy outcomes. The specific aims are 1) to determine whether preconception selfreported stress is associated with fecundability and 2) examine the association between preconception self-reported stress and the risk of spontaneous abortion. 


\begin{tabular}{|c|c|c|c|c|}
\hline $\begin{array}{l}\text { Author } \\
\text { (Year) }\end{array}$ & $\begin{array}{l}\text { Study design } \\
\text { and sample size }\end{array}$ & Stress exposure & Analysis & Results \\
\hline $\begin{array}{l}\text { Hjollun } \\
\text { d et al. } \\
\text { (1999) }\end{array}$ & $\begin{array}{l}\text { Prospective } \\
\text { cohort }(\mathrm{N}=430)\end{array}$ & $\begin{array}{l}\text { Distress scores } \\
\text { from the General } \\
\text { Health } \\
\text { Questionnaire }\end{array}$ & $\begin{array}{l}\text { Logistic } \\
\text { regression } \\
\text { model }\end{array}$ & $\begin{array}{l}\text { Cycles with a higher distress } \\
\text { score had a lower } \\
\text { probability of conception } \\
\text { (FOR } 0.6 ; 95 \% \text { CI } 0.4-1.0 \text { ) } \\
\text { with a lower odds ratio for } \\
\text { women with cycles } \geq 35 \\
\text { days (FOR } 0.1 ; 95 \% \text { CI } \\
0.01-0.4 \text { ) compared to } \\
\text { women }<35 \text { days (FOR } 0.9 \text {; } \\
95 \% \text { CI } 0.5-1.4 \text { ) }\end{array}$ \\
\hline
\end{tabular}

$\begin{array}{lllll}\begin{array}{l}\text { Louis } \\ \text { et al. }\end{array} & \begin{array}{l}\text { Prospective } \\ \text { cohort }(\mathrm{N}=274)\end{array} & \begin{array}{l}\text { Salivary } \alpha- \\ \text { amylase and } \\ \text { salivary cortisol } \\ \text { collections on day } \\ 6 \text { of each cycle }\end{array} & \begin{array}{l}\text { Discrete time } \\ \text { survival } \\ \text { analysis }\end{array} & \begin{array}{l}\text { Salivary } \alpha \text {-amylase but not } \\ \text { cortisol amylase negatively } \\ \text { associated with fecundity }\end{array} \\ & & & \text { (FOR 0.85; 95\% CI 0.67- } \\ & & & 1.09)\end{array}$

$\begin{array}{ll}\text { Lynch } & \text { Prospective } \\ \text { et al. } & \text { cohort }(\mathrm{N}=339)\end{array}$

(2012)

Lynch Prospective

et al. cohort $(\mathrm{N}=401)$

(2014)

$\begin{array}{ll}\text { Stress data from } & \text { Cox } \\ \text { self-administered } & \text { proportional } \\ \text { questionnaires; } & \text { hazards models } \\ \text { salivary } \alpha \text {-amylase } & \text { and discrete } \\ \text { and salivary } & \text { time survival } \\ \text { cortisol collections } & \text { analysis } \\ \text { on day } 6 / \text { cycle } & \end{array}$

Salivary $\alpha$ -

amylase and

salivary cortisol

collection on the

morning following

enrollment and the

morning following

their first observed

menses in the study

Discrete time survival analysis. Risk ratio for infertility using Poisson regression with robust standard errors
No association between psychosocial measures and fecundity. No correlation between psychosocial measures and biomarkers of stress (salivary $\alpha$-amylase and cortisol)
Lower fecundity for women with the highest tertile of $\alpha$ amylase (FOR 0.71; 95\% CI 0.51-1.00). This decreased fecundity translates into a .2-fold increased risk of infertility among these women [relative risk (RR) 2.07; 95\% CI 1.04-4.11)

No association between salivary cortisol and fecundability 
Literature review table 2: Epidemiological studies examining self-reported stress and spontaneous abortion

\begin{tabular}{|c|c|c|}
\hline $\begin{array}{l}\text { Author } \\
\text { (Year) }\end{array}$ & $\begin{array}{l}\text { Study design } \\
\text { and sample size }\end{array}$ & Stress exposure \\
\hline
\end{tabular}

\begin{tabular}{llll}
\hline Hjollund & Prospective & Daily diary scores: 0= no & Cox \\
et al. & cohort $(\mathrm{N}=430)$ & strain, 1= light strain, 2= & proportional \\
$(2000)$ & during the first & moderate strain, 3= very high & hazards \\
& trimester & strain & models and \\
& & & discrete time \\
& & & survival \\
& & analysis
\end{tabular}

Women with higher physical strain than average at day 6-9 after the estimated day of ovulation had a higher risk of SA compared to those with lower physical strain (RR 2.5; $95 \%$ CI $1.3-4.6$ )

$\begin{array}{llll}\begin{array}{l}\text { Macono } \\ \text { chie et }\end{array} & \begin{array}{l}\text { Case-control } \\ (\mathrm{N}=603) \text { during }\end{array} & \begin{array}{l}\text { Behavioral questionnaire } \\ \text { addressing emotional well }\end{array} & \begin{array}{l}\text { Logistic } \\ \text { regression }\end{array} \\ \text { al. } & \text { the first } & \text { being and stressful/traumatic } & \text { model } \\ (2007) & \text { trimester } & \text { events } & \end{array}$

Nepoma Prospective Urinary cortisol collections nschy et cohort $(\mathrm{N}=61)$ every other day each week al. during the first 3

(2006) weeks

\begin{tabular}{|c|c|c|}
\hline $\begin{array}{l}\text { Arck et } \\
\text { al. } \\
(2008)\end{array}$ & $\begin{array}{l}\text { Prospective } \\
\text { cohort }(\mathrm{N}=864) \\
\text { during the first } \\
\text { trimester (weeks } \\
4-12 \text { ) }\end{array}$ & $\begin{array}{l}\text { Blood samples tested for } \\
\text { CRH concentration and } \\
\text { progesterone upon } \\
\text { recruitment }\end{array}$ \\
\hline
\end{tabular}

Wainsto Retrospective Pre- conception exposure $=$ ck et al. cohort $(\mathrm{N}=1345)$ mean weekly alarms during (2013) until second trimester $(22$ weeks) the 6 months before conception. Exposure during pregnancy $=$ mean weekly alarms from conception until SA or until end of week 22
RR using the Rao-Thomas modified $F$ test

Logistic regression model with accordance to Hosmer Lemeshow technique

Multivariable logistic regression
Women who reported feeling stressed had a higher risk of SA compared to those who felt happy/relaxed $(\mathrm{OR}=2.47 ; 95 \% \mathrm{CI}$ 2.02-3.02). Risk of SA increased with higher number of stressful events $(\geq 3)(\mathrm{OR}=2.36$; 95\% CI 1.05- 5.32)

Women with higher levels of cortisol had a higher risk of SA (RR $=2.7$; 95\% CI 1.2-6.2) than those with normal cortisol levels

Women with low progesterone levels $(\leq 12$ $\mathrm{ng} / \mathrm{ml}$ ) had an increased risk of SA (OR 0.51; 95\% CI $0.28-0.91$ ); increased after adjusting for BMI and age (OR $7.1 ; 95 \%$ CI 2.8 - 17.9)

Women exposed to higher mean of weekly alarms overall had a higher risk of SA than those not exposed $(\mathrm{OR}=1.59 ; 95 \% \mathrm{CI}=$ 1.17-2.2) 


\section{METHODS}

\section{Study population}

The Mount Sinai Study of Women Office Workers (MSSWOW) was originally designed to evaluate the reproductive health of women office workers 40 years of age and younger. Through 1990-1994women were enrolled from 14 companies and government agencies in New York, New Jersey, and Massachusetts (Marcus et al. 1996, Marcus et al. 2000). Women who were sexually active while using inconsistent or no oral contraceptives in the month before the baseline questionnaire were eligible for the study. Women using oral contraceptives or intrauterine device and women diagnosed with polycystic ovaries, had a hysterectomy, or currently infertile (attempting to conceive for more than 12 months)were not eligible (Marcus et al. 1996, Marcus et al. 2000). After completing a baseline questionnaire for demographic information and medical history, women were asked to complete daily diaries every day during the cycle. This included information about caffeinated and alcoholic beverages, cigarettes, exercise, exposure to video display terminals, intercourse, menstruation, birth control, and stress $(\mathrm{N}=855)$. Early morning urine (first void before breakfast) was collected during the first 2 days of each cycle, where day 1 was defined as the first day of menstruation. If pregnancy occurred during a cycle, women collected urine samples on the expected day of menses, calculated from the average cycle length reported during the intake interview. Women were followed until pregnant or until the study end, for an average of 8 menstrual cycles 
(maximum 20 cycles). Pregnancy outcomes were ascertained at the end of clinical pregnancy.

\section{Study eligibility}

For the current study, only women who had completed daily diaries $(\mathrm{N}=563)$ were included. We excluded from our fecundability analysis 40 women who did not have any stress data (resulting in $\mathrm{N}=523$ ) and 28 additional women who had less than 30 days of stress information (resulting in $\mathrm{N}=495$ ). The final sample size was 405 women after excluding 90 participants with missing data for the following important covariates: age, BMI, alcohol consumption, pregnancy intention, and intercourse frequency (see Figure 4).

For evaluating the probability of spontaneous abortion, we limited the population to women who became pregnant ( $\mathrm{N}=168$ women, 196 pregnancies). From this analysis, women with molar pregnancies, ectopic pregnancies, and pregnancies with unknown outcomes were excluded. The final sample size was 159 women with 178 total pregnancies (159 first pregnancies and 19 subsequent pregnancies).

\section{Exposure assessment}

Participants were asked to complete diaries until pregnant or for 12 cycles of follow-up. Daily diaries contained information regarding menstrual characteristics, intercourse frequency, contraceptive use, alcohol consumption, caffeine, smoking, and stress levels. Women reported stress on a scale with 1 being the lowest and 4 the highest. Daily diaries have been used in other studies based on a point score system ranging from "no stress" to "high stress" (Hjollund et al. 1999, Wang et al. 2004). 
To examine stress exposure throughout different phases in a woman's menstrual cycle, three separate methods of classifying stress were created. The first method simply uses the woman's mean stress particular to each cycle. The second method uses the mean stress over each cycle's ovulatory window. The estimated day of ovulation was defined as the day 14 days prior to the onset of the next menses. The mean stress over the ovulatory period were defined as 18 days before the onset of the next menses until the estimated day of ovulation (days -18 to -14; thus creating an ovulatory window 5 days in duration). Thus, the estimated period includes the end of the follicular phase and the day of ovulation (Goodman 2008). The third method is the mean stress over the implantation period, which occurs during the luteal phase. This was ascertained from the estimated day of ovulation until 10 days before the onset of the next menses (days -12 to -5 ).

\section{Covariate assessment}

Upon entry into the study, participants were interviewed for demographic and anthropometric characteristics, and reproductive history. Data collected included age, body mass index (BMI, $\mathrm{kg} / \mathrm{m}^{2}$ ), ethnicity, race, marital status, education, pregnancy history, and paternal reproductive characteristics and medical issues. The frequency of unprotected intercourse, average weekly number of cigarettes smoked, alcoholic and caffeinated beverages, and menstrual cycle characteristics (length and variability) were calculated from the daily diaries. Cycle length was defined as the number of days between the first day of bleeding until the day prior to the next bleeding.

\section{Fecundability and spontaneous abortions}

Pregnancies were previously assayed for MSSWOW and were defined by human 
chorionic gonadotropin (hCG) levels greater than $0.25 \mathrm{ng} / \mathrm{mL}$ for two consecutive days of urine samples. Two laboratories assayed samples for hCG levels including the Core Laboratory at the Irving Center for Clinical Research at Columbia University and the Center for Clinical Research at Mount Sinai School of Medicine (Small et al. 2006). Split sample comparison between both labs allowed for similar results.

Time to pregnancy (fecundability) was assessed by counting the number of cycles up to and including the cycle of pregnancy. Of the 405 women included in our study, there were 154 pregnancies. Pregnancy outcomes were categorized as live birth, voluntary induced abortion, spontaneous abortion, blighted ovum, ectopic pregnancy, therapeutic induced abortion, subclinical abortion, and molar pregnancy. Subclinical spontaneous abortion was defined as a cycle with an elevated hCG levels followed by a cycle with no elevation of hCG (Small et al. 2006). All clinical pregnancies and clinical spontaneous abortions were confirmed by physician diagnosis.

\section{Statistical analysis for fecundability}

Statistical significance testing was conducted through Chi-square tests or Fisher"s exact test to evaluate the distribution of demographic data and covariates across categories of study participation and by pregnancy outcomes. The analysis of fecundability was evaluated for first pregnancies and a separate analysis was conducted that included subsequent pregnancies. Discrete survival analysis was used to determine whether self-reported stress levels were associated with fecundability (time to pregnancy). This approach is statistically more powerful than dichotomizing reproductive success as fertile/infertile (Baird et al. 1986). The discrete time hazard is defined as the 
probability that a woman became pregnant in a given menstrual cycle conditional on a pregnancy not occurring in prior cycles. The likelihood for a discrete time hazard rate is equivalent to that of binary regression models (Scheike et al. 2006). The discrete time hazard was included in the model through indicator variables for each cycle a woman was at risk for pregnancy.

\section{Evaluation and selection of covariates}

Logistic regression was used to estimate the impact of stress and important covariates (adjusted one at a time) on fecundability, and the maximum likelihood estimates, standard errors and P-values were reported (Supplemental Tables 1 and 2). A set of relevant covariates were chosen through review of literature and a directed acyclic graph (DAG)(Figure 5). Two criteria were used to decide whether a covariate should be included in the multivariable logistic model. First, according to the method of Hosmer and Lemeshow (2000), only those covariates with a P-value greater than 0.2 from the bivariate logistic regression were taken forward to the multivariable logistic model (Hosmer et al. 2000). Additionally, a covariate was not included if its removal from the model did not result in a change in the estimated regression parameter for stress changing $>10 \%$. The combination of these methods resulted in a parsimonious model.

Fecundability odds ratio (FOR), which represents the ratio of the odds of conception in one group to the odds of the referent group, with associated $95 \%$ confidence intervals (CI) and P-values were generated from the multivariable model. Three models were generated to assess the association of fecundability, using the three methods of categorizing of stress exposure throughout the phases of menstrual cycle (full cycle, ovulatory window, and implantation window). 
Covariate values were obtained from the cycle prior to index cycle. In the models, BMI, maternal age, alcoholic consumption (drinks per day) and cigarettes (per day) were modeled both continuously and categorically (based on prior literature). Race was divided into categories based on prior literature. Intercourse frequency during the ovulatory window was calculated from daily diaries and left as a continuous cyclespecific covariate. Pregnancy intention and ever pregnant were defined as dichotomous variables.

Sensitivity analyses were conducted for participants who had at least $90 \%$ stress data during a particular cycle to account for any missing stress data and to assess what impact including all participants had on the overall analysis. Since over $75 \%$ of the study population was white, a second sensitivity analysis restricted to only whites with $90 \%$ stress data was conducted to examine if the main findings were consistent.

An additional analysis was conducted to assess the impact of each woman s average stress relative to her average stress during the ovulatory window on fecundability. For this analysis, stress was dichotomized into high stress (1) and low stress $(0)$. If the individual mean stress over the ovulatory window was greater than the average stress during the ovulatory window, then it was defined as high stress (1)and if the individual mean stress during the ovulatory window was less than or equal to her average stress then it was defined as low stress (0).

\section{Statistical analysis for risk of spontaneous abortion}

Out of 196 pregnancies (168 women) that occurred during the study, only 178 pregnancies (159 women) were eligible after the exclusion criteria. Among these women, there were 40 spontaneous abortions. Statistical significance testing was conducted 
through Chi-square tests for demographic data of women with live births and women with spontaneous abortions. The analysis of spontaneous abortions was evaluated for first pregnancies and a separate analysis was conducted for all pregnancies.

The bivariate analysis was conducted through logistic regression to determine which covariates to include in the multivariate model. A set of relevant covariates were chosen through review of literature and a directed acyclic graph (DAG) (Figure 3). As in the fecundability analysis, two inclusion criteria were used for covariates. First, the Hosmer Lemeshow (2000) method was used to include covariates with a P-value greater than 0.2 one by one into the multivariate model(Hosmer et al. 2000). Second, the covariate was only kept if its inclusion changed the effect estimate for the main exposure (stress) by $>10 \%$. A multivariable logistic regression approach was used to model the risk of spontaneous abortion across the three periods of stress exposure. This was done for first pregnancies and again for all pregnancies.

A second analysis was conducted to assess the impact of each woman ${ }^{\text {ee }}$ s average stress relative to her average stress during the cycle on the risk of spontaneous abortion. For this analysis, stress was dichotomized into high stress (1) and low stress (0). If the individual mean stress was less than the mean stress during the cycle, then it was defined as low stress (0) and if the individual mean stress was greater or equal to the mean stress then it was defined as high stress (1).

The Institutional Review Board at Mount Sinai School of Medicine, New York, NY, and Emory University, Atlanta, GA, approved the protocols and all participants provided informed consent. Additionally, the Institutional Review Board at the University of Louisville approved this analysis. 
Figure 4: Study flow diagram for eligibility

No birth control in the month before baseline questionnaire

$\mathrm{N}=855$

Completed at least one daily diary

$\mathrm{N}=563$

Completed at least one daily

diary including stress data

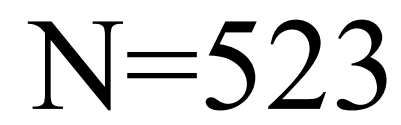

At least 30 days of stress data

$\mathrm{N}=487$

No missing data for important

covariates; Final sample size

for fecundability analysis

$\mathrm{N}=405$ 
Figure 5: Directed acyclic graph on stress and fecundability

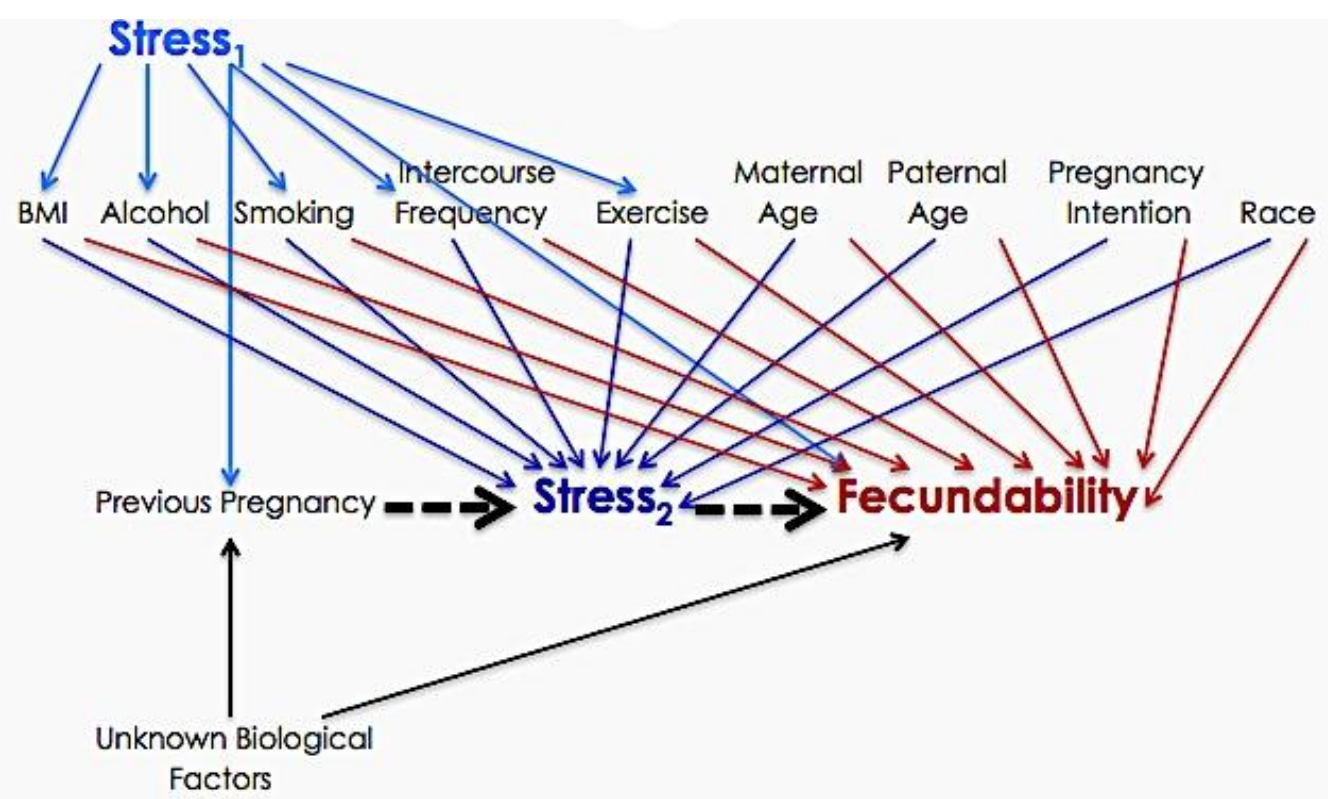

Figure 6: Directed acyclic graph on stress and spontaneous abortion

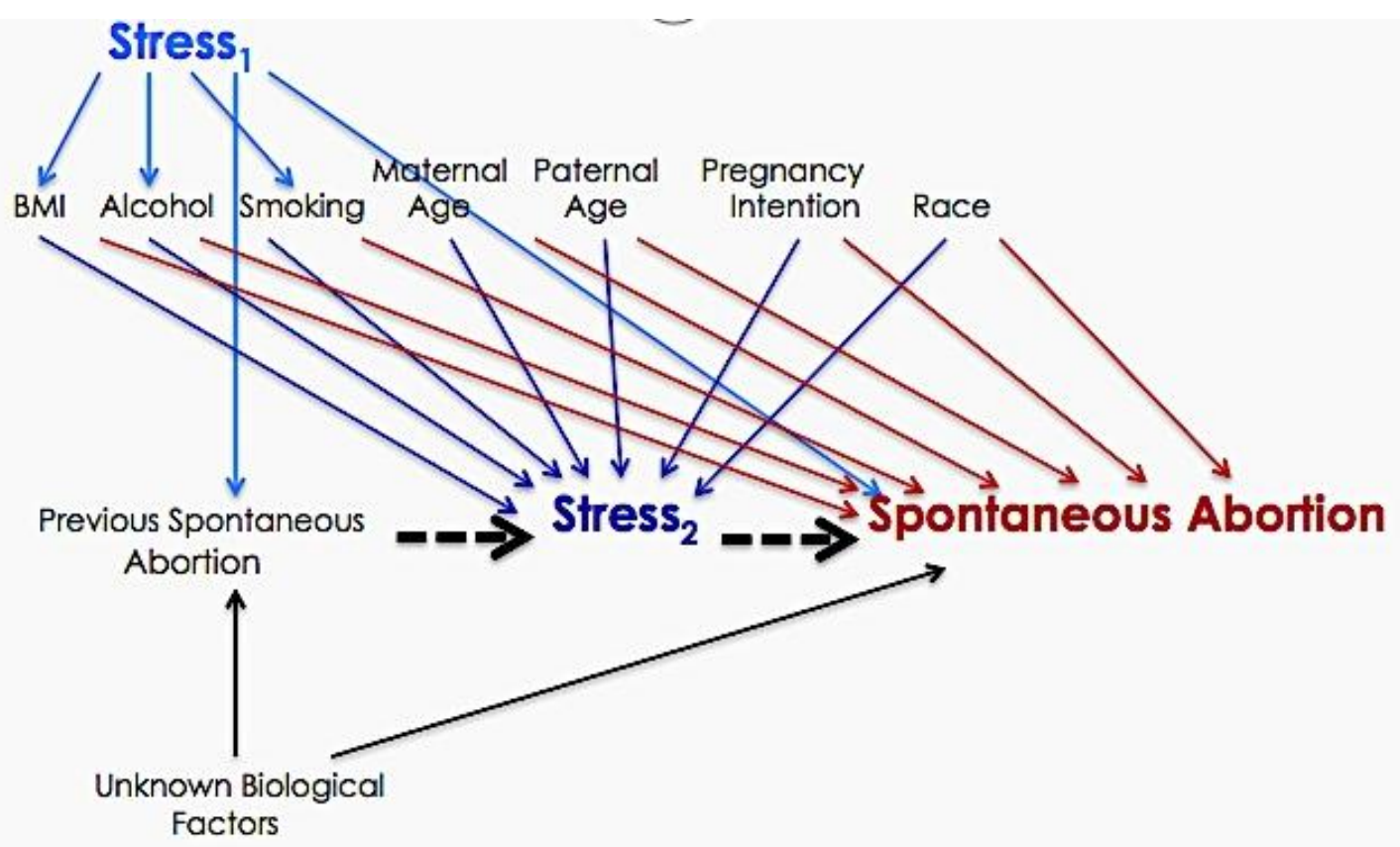




\section{RESULTS}

\section{Study population}

The women in our study were mostly white, non-Hispanic with a normal BMI $\left(20-25 \mathrm{~kg} / \mathrm{m}^{2}\right)$, above 30 years of age, and married (Table 1). Out of 487 women with self-reported stress, only 405 had both stress and relevant covariate data. Chi-square tests comparing characteristics of the 405 women with all covariate data vs. the 82 without such data demonstrated differences for specific variables including age, race, ethnicity, marital status, alcohol consumption, intercourse frequency, and stress (Table 1). With regards to behavioral factors, almost half of the women were non-smokers (47\%) with a mean value of 13 cigarettes/ day among the smokers and alcoholic consumption was $<1$ drink per day (75\%) with a median of 0.25 drinks per day. The median value of stress was 1.93 on a scale from 1 to 4 ( 1 being the lowest and 4 being the highest). Out of 487 , 168 women were pregnant, including 168 first pregnancies and 28 subsequent pregnancies. Approximately a quarter $(26 \%)$ of the women reported they were trying to get pregnant.

\section{Fecundability study population}

From the 405 women who had both stress and relevant covariate data, there were 135 women who got pregnant with a total of 161 pregnancies (135 first pregnancies 26 subsequent pregnancies). No women were excluded based on pregnancy outcome for the 
fecundability analysis because this variable was not the outcome of interest. Chi-square tests comparing those women who got pregnant $(\mathrm{N}=135)$ with those who did not get pregnant $(\mathrm{N}=270)$ demonstrated significant differences for specific characteristics including age, marital status, education, intercourse frequency, and pregnancy intention (Table 2).

\section{Effects of stress on fecundability}

A bivariate logistic regression analysis was conducted to determine which variables to include as possible confounders in the final model (Supplemental Tables 1 and 2). The bivariate analysis confirmed age, BMI, alcohol consumption, pregnancy intention, and intercourse frequency as confounders for the association between stress and fecundability. Age and BMI were left as categorical variables due to an absence of a linear trend, and alcohol consumption was left as a continuous variable because a linear trend was observed for this variable. Race was not included because it was within $10 \%$ of changing the beta estimate for the exposure and there were too few people in the nonwhites group for a comparison to the white group. Smoking was eliminated from the model due to no change in the effect estimate for the stress exposure when adding or removing smoking from the model. The other potential covariates had a P-value greater than 0.20, and therefore did not meet the Hosmer-Lemeshow criterion for inclusion (Hosmer et al. 2000).

Throughout the models, sample size numbers may not match up due to missing covariate data. The results presented in Table 4 display the multivariable model including the three different windows of stress exposure and relevant covariates associated with fecundability. Fecundability odds ratios $($ FOR $)<1$ are indicative of reduced fecundability 
(longer time to pregnancy) and P-values $<0.05$ were considered statistically significant. Average stress during the cycle and during the implantation window decreased fecundability but not significantly $(\mathrm{FOR}=0.75 ; 95 \% \mathrm{CI}(0.57-1.01)$ and $\mathrm{FOR}=0.86 ; 95 \%$ CI (0.65-1.13), respectively). However, cycles with higher stress during the ovulatory window had a 35\% reduced odds of pregnancy after adjustment compared to cycles with lower stress ( $\mathrm{FOR}=0.65 ; 95 \% \mathrm{CI} 0.50-0.87)$. Among all three models, higher maternal age (35-41 years), higher BMI ( $\left.>30 \mathrm{~kg} / \mathrm{m}^{2}\right)$, and a higher intake of alcohol per day ( $>1$ drink) were associated with significantly decreased fecundability. On the other hand, a higher frequency of unprotected intercourse and intention to get pregnant were associated with increased fecundability. These results were similar for all pregnancies (Supplemental Table 3).

There was some missing stress data; a sensitivity analysis was therefore conducted to assess the impact of missing stress data on the results. In the sensitivity analysis, only cycles where stress was recorded for $>90 \%$ of the days in the cycle were included. The results were similar to the initial analysis albeit loss of significance for maternal age (Supplemental Tables 5 and 6). To examine if these effects persisted after restricting to only whites in the study population, another sensitivity analysis was conducted ( $\mathrm{N}=330$ women) and results were similar to the initial analysis (Supplemental Tables 7 and 8).

Because the strongest effects of stress on fecundability were observed during the ovulatory window, a separate analysis was conducted to examine the effect of each woman"s average stress during the ovulatory window relative to her average stress over the study period. As shown in Table 5, higher stress during the ovulatory window reduced fecundability by $30 \%(\mathrm{OR}=0.70 ; 95 \%$ CI $0.47-1.05)$. Similar results were 
observed when subsequent pregnancies were also included (Supplemental Table 4).

\section{Spontaneous abortion study population}

From the 487 women with stress data, there were a total of 168 first pregnancies (during the study) and after excluding women with molar pregnancies, ectopic pregnancies, and unknown outcomes, the number of pregnancies was 159. Out of 159 pregnancies, there were 119 live births and 40 spontaneous abortions. As shown in Table 3, the 119 live births were not significantly different from the subset of 40 spontaneous abortions for any of the characteristics except alcohol consumption and pregnancy intention.

\section{Effects of stress on spontaneous abortion}

To determine which relevant covariates to include in the multivariable model, a bivariate logistic regression analysis was generated (Supplemental Tables 9 and 10). From these results, only age (continuous), alcohol consumption (continuous) and pregnancy intention were below the 0.2 significance level and were therefore included in the multivariable logistic regression model.

Across all phases of the menstrual cycle, stress did not significantly affect the risk of spontaneous abortion (Table 6). In fact, stress seems to decrease the risk after adjusting for pregnancy intention. Older age and higher alcohol consumption increased the risk of spontaneous abortion significantly in all three time periods when all pregnancies were included in the model (Supplemental Table 11) but only alcohol consumption was significant for first pregnancies, possibly due to decreased sample size.

A separate analysis was conducted to examine the effect of each woman"s average 
stress during a particular cycle relative to the average stress during the entire study on spontaneous abortion. The results in Table 7 show a significant association between higher stress during the index cycle and spontaneous abortion (OR=2.52, 95\% CI 1.17 5.43). Effects were similar for all pregnancies (Supplemental Table 12). 
Table 1: Characteristics of Study Participants with Self-Reported Stress and Covariates in the Mount Sinai Study of Women Office Workers

\begin{tabular}{|c|c|c|c|c|}
\hline & $\begin{array}{c}\text { Women } \mathrm{N}(\%) \\
\text { All eligible women } \\
\text { for fecundability } \\
\text { analysis } \\
\text { (N=487 women) }\end{array}$ & $\begin{array}{c}\text { Women } \mathrm{N}(\%) \\
\text { Self-reported stress } \\
\text { with all fecundability } \\
\text { covariates } \\
\text { (N=405 women) }\end{array}$ & $\begin{array}{c}\text { Women N (\%) } \\
\text { Self-reported stress } \\
\text { without all } \\
\text { fecundability } \\
\text { covariates } \\
\text { (N=82 women) }\end{array}$ & $\begin{array}{r}\text { Chi-Square } \\
\text { P-value* }\end{array}$ \\
\hline \multicolumn{5}{|l|}{ Age $(\text { years })^{\dagger}$} \\
\hline $19-24$ & $40(8.20)$ & $36(8.90)$ & $4(4.88)$ & 0.03 \\
\hline $25-29$ & $149(30.6)$ & $133(32.8)$ & $16(19.5)$ & \\
\hline $30-34$ & $169(34.7)$ & $136(33.6)$ & $33(40.2)$ & \\
\hline $35-41$ & $129(26.5)$ & $100(24.7)$ & $29(35.4)$ & \\
\hline \multicolumn{5}{|l|}{$\begin{array}{l}\text { Body mass index } \\
\left(\mathrm{kg} / \mathrm{m}^{2}\right)^{\dagger}\end{array}$} \\
\hline$<20$ & $71(16.7)$ & $72(17.8)$ & $4(10.8)$ & 0.56 \\
\hline $20-25$ & $216(51.0)$ & $202(49.8)$ & $22(59.5)$ & \\
\hline $25.1-30$ & $84(19.8)$ & $78(19.3)$ & $8(21.6)$ & \\
\hline$>30$ & $53(12.5)$ & $53(13.1)$ & $3(8.10)$ & \\
\hline Missing & 63 & --------- & 45 & \\
\hline \multicolumn{5}{|l|}{$\operatorname{Race}^{\dagger}$} \\
\hline White & $375(77.0)$ & $330(81.5)$ & $45(54.9)$ & $<0.0001$ \\
\hline Black & $63(12.9)$ & $46(11.4)$ & $17(20.7)$ & \\
\hline Asian & $14(2.90)$ & $11(2.7)$ & $3(3.70)$ & \\
\hline Other & $35(7.20)$ & $18(4.4)$ & $17(20.7)$ & \\
\hline \multicolumn{5}{|l|}{ Ethnicity ${ }^{\dagger}$} \\
\hline Non-Hispanic & $449(93.0)$ & $385(95.5)$ & $64(80.0)$ & $<0.0001$ \\
\hline Hispanic & $34(7.00)$ & $18(4.50)$ & $16(20.0)$ & \\
\hline Missing & 4 & 2 & 2 & \\
\hline \multicolumn{5}{|l|}{ Marital status ${ }^{\dagger}$} \\
\hline Married & $320(65.7)$ & $264(65.2)$ & $56(68.3)$ & 0.03 \\
\hline $\begin{array}{l}\text { Single (never } \\
\text { married) }\end{array}$ & $125(25.7)$ & $111(27.4)$ & $14(17.1)$ & \\
\hline $\begin{array}{l}\text { Divorced/separat } \\
\text { ed/widowed }\end{array}$ & $42(8.60)$ & $30(7.40)$ & $12(14.6)$ & \\
\hline \multicolumn{5}{|l|}{ Highest education $^{\dagger}$} \\
\hline $\begin{array}{l}\text { High school or } \\
\text { less/ Tech school }\end{array}$ & $124(25.5)$ & $95(23.5)$ & $29(35.4)$ & 0.05 \\
\hline Some college & $164(33.7)$ & $135(33.3)$ & $29(35.4)$ & \\
\hline College graduate & $143(29.3)$ & $128(31.6)$ & $15(18.3)$ & \\
\hline Graduate school & $56(11.5)$ & 47 (11.6) & $9(10.9)$ & \\
\hline \multicolumn{5}{|l|}{ Smoking status ${ }^{\dagger}$} \\
\hline Never & $198(46.6)$ & $186(46.0)$ & $20(52.6)$ & 0.71 \\
\hline Former & $119(28.0)$ & $115(28.4)$ & $10(26.3)$ & \\
\hline Current & $108(25.4)$ & $104(25.6)$ & $8(21.1)$ & \\
\hline Missing & 62 & ------- & 44 & \\
\hline
\end{tabular}


Cigarettes smoked preconception (per day) ${ }^{\ddagger}$

0 cigarettes

1-9 cigarettes

10-19 cigarettes

$20+$ cigarettes

Missing

Alcohol

consumption -

preconception (per day) ${ }^{\ddagger}$

0 drinks

$\leq 1$ drink

$>1$ drinks

Missing

Frequency of unprotected intercourse during ovulatory window

0 times

$\leq 1$ time

1 to 4 times

$>4$ times

Missing

Stress - scale from 1 (least stress) to 4 (most stress)

$1^{\text {st }}$ quartile

$(<1.50)$

$2^{\text {nd }}$ quartile

(1.50-1.92)

$3^{\text {rd }}$ quartile

$(1.93-2.33)$

$4^{\text {th }}$ quartile

$(>2.33)$

Trying to get

pregnant ${ }^{\dagger}$

Yes

No

Missing

Ever pregnant (at

study initiation)

Yes

No

Missing
$254(59.8)$

$110(25.9)$

$32(7.50)$

$29(6.80)$

62

$46(10.8)$

$317(74.6)$

$62(14.6)$

62

$30(7.40)$

$311(76.8)$

64 (15.8)

----------

$16(42.1)<0.0001$

$20(52.6)$

$2(5.30)$

44

0.50

$7(18.4)$

$3(7.90)$

$1(2.60)$

44

$81(19.0)$

$69(17.0)$

$14(36.8)$

0.006

$101(23.8)$

$102(25.2)$

$3(7.90)$

$130(32.1)$

$14(36.8)$

105 (24.7)

104 (25.7)

7 (18.5)

44

$129(26.5)$

68 (16.8)

26 (31.6)

0.02

$116(23.8)$

115 (28.4)

$18(22.0)$

$122(25.1)$

113 (27.9)

$20(24.4)$

$120(24.6)$

109 (26.9)

$18(22.0)$

$104(26.3)$

$102(25.2)$

303 (74.8)

$6(66.7)$

0.70

91

$3(33.3)$

73

274 (64.5)

255 (63.0)

27 (71.1)

0.32

$151(35.5)$

$150(37.0)$

11 (28.9)

44 
Became pregnant

during study

Yes

$196(48.4)$

$135(33.3)$

209 (51.6)

$270(66.7)$

$26(31.7)$

0.78

Unknown (no

82

--------

urine samples)

Pregnancy outcome ${ }^{\S}$

Live birth

Voluntary induced

abortion

Ectopic pregnancy

Molar pregnancy

Unknown

$113(67.2)$

8 (4.8)

89 (65.9)

$7(5.2)$

$56(68.3)$

Spontaneous

$1(0.6)$

$1(0.6)$

$5(3.0)$

$2(1.4)$

$1(0.8)$

$1(0.8)$

$40(23.8)$

35 (25.9)

$22(84.6)$

0.24 abortion

${ }^{*}$ Chi-square $\mathrm{P}$-values were calculated by comparing women with both self-reported stress and covariates $(\mathrm{N}=405)$ with women with self-reported stress but without covariates $(\mathrm{N}=82)$. Missing values were not included in these calculations and percentages reflect non-missing data

${ }^{\dagger}$ At baseline

"Mean over duration of study

${ }^{\S}$ First pregnancies only 
Table 2: Characteristics of Pregnant and Non-pregnant Women in the Mount Sinai Study of Women Office Workers

\begin{tabular}{|c|c|c|c|c|}
\hline & $\begin{array}{c}\text { Women N (\%) } \\
\text { Self-reported stress } \\
\text { with covariates } \\
(\mathrm{N}=405 \text { women })\end{array}$ & $\begin{array}{l}\text { Women N (\%) } \\
\text { Not pregnant } \\
\text { (N=270 women) }\end{array}$ & $\begin{array}{c}\text { Women } \mathrm{N}(\%) \\
\text { Pregnant } \\
(\mathrm{N}=135 \text { women })\end{array}$ & $\begin{array}{l}\text { Chi Square } \\
\text { P-value* }\end{array}$ \\
\hline \multicolumn{5}{|l|}{ Age (years) ${ }^{\dagger}$} \\
\hline $19-24$ & $36(8.90)$ & $28(10.4)$ & $8(5.9)$ & 0.03 \\
\hline $25-29$ & $133(32.8)$ & $81(30.0)$ & $52(38.5)$ & \\
\hline $30-34$ & $136(33.6)$ & $85(31.5)$ & $51(37.8)$ & \\
\hline $35-41$ & $100(24.7)$ & $76(28.1)$ & $24(17.8)$ & \\
\hline \multicolumn{5}{|l|}{$\begin{array}{l}\text { Body mass index } \\
\left(\mathrm{kg} / \mathrm{m}^{2}\right)^{\dagger}\end{array}$} \\
\hline$<20$ & $72(17.8)$ & $45(16.7)$ & $27(20.0)$ & 0.18 \\
\hline $20-25$ & $202(49.8)$ & $130(48.1)$ & $72(53.3)$ & \\
\hline $25.1-30$ & $78(19.3)$ & $53(19.6)$ & $25(18.5)$ & \\
\hline$>30$ & $53(13.1)$ & $42(15.6)$ & $11(8.2)$ & \\
\hline \multicolumn{5}{|l|}{$\operatorname{Race}^{\dagger}$} \\
\hline White & $330(81.5)$ & $218(80.7)$ & $112(83.0)$ & 0.08 \\
\hline Black & $46(11.4)$ & $30(11.1)$ & $16(11.9)$ & \\
\hline Asian & $11(2.7)$ & $11(4.1)$ & 0 & \\
\hline Other & $18(4.4)$ & $11(4.1)$ & $7(5.1)$ & \\
\hline \multicolumn{5}{|l|}{ Ethnicity $^{\dagger}$} \\
\hline Non-Hispanic & $385(95.5)$ & $255(94.8)$ & $130(97.0)$ & 0.44 \\
\hline Hispanic & $18(4.50)$ & $14(5.2)$ & $4(3.0)$ & \\
\hline Missing & 2 & 1 & ------- & \\
\hline \multicolumn{5}{|l|}{ Marital status ${ }^{\dagger}$} \\
\hline Married & $264(65.2)$ & $158(58.5)$ & $106(78.5)$ & 0.0003 \\
\hline $\begin{array}{l}\text { Single (never } \\
\text { married) }\end{array}$ & $111(27.4)$ & $87(32.2)$ & $24(17.8)$ & \\
\hline $\begin{array}{l}\text { Divorced/separated/ } \\
\text { widowed }\end{array}$ & $30(7.40)$ & $25(9.3)$ & $5(3.7)$ & \\
\hline \multicolumn{5}{|l|}{ Highest education ${ }^{\dagger}$} \\
\hline $\begin{array}{l}\text { High school or } \\
\text { less/ Tech school }\end{array}$ & $95(23.5)$ & $64(23.7)$ & $31(23.0)$ & 0.02 \\
\hline Some college & $135(33.3)$ & $96(35.6)$ & $39(28.9)$ & \\
\hline College graduate & $128(31.6)$ & $88(32.6)$ & $40(29.6)$ & \\
\hline Graduate school & $47(11.6)$ & $22(8.1)$ & $25(18.5)$ & \\
\hline \multicolumn{5}{|l|}{ Smoking status ${ }^{\dagger}$} \\
\hline Never & $186(46.0)$ & $121(44.8)$ & $65(48.2)$ & 0.26 \\
\hline Former & $115(28.4)$ & $73(27.0)$ & $42(31.1)$ & \\
\hline Current & $104(25.6)$ & $76(28.2)$ & $28(20.7)$ & \\
\hline
\end{tabular}


Cigarettes smoked preconception (per day)

0 cigarettes

1-9 cigarettes

10-19 cigarettes

$20+$ cigarettes

\section{Alcohol consumption \\ - preconception (per \\ day) ${ }^{*}$ \\ 0 drinks \\ $\leq 1$ drink \\ $>1$ drinks}

Frequency of

unprotected

intercourse during

ovulatory window
0 times
$\leq 1$ time
1 to 4 times
$>4$ times

69 (17.0)

$102(25.2)$

$130(32.1)$

104 (25.7)

\author{
$30(7.40)$ \\ $311(76.8)$ \\ 64 (15.8)
}
$19(7.0)$
$202(74.8)$
49 (18.2)

$21(7.8)$

$22(8.2)$

$63(23.3)$

$81(30.0)$

77 (28.5)

49 (18.2)
90 (66.7)

$2921.5)$

$8(5.9)$

$8(5.9)$

0.23
$11(8.2)$
$109(80.7)$

$15(11.1)$

0.18

$6(4.4)$

$<0.0001$

$21(15.6)$

$53(39.3)$

55 (40.7)

Stress - scale from 1

(least stress) to 4

(most stress) $)^{\ddagger}$

$1^{\text {st }}$ quartile

$(<1.50)$

$2^{\text {nd }}$ quartile

(1.50-1.92)

$3^{\text {rd }}$ quartile

$(1.93-2.33)$

$4^{\text {th }}$ quartile

$(>2.33)$

$68(16.8)$

44 (16.3)

24 (17.8)

0.22

$115(28.4)$

69 (25.5)

$46(34.1)$

$113(27.9)$

$82(30.4)$

$31(23.0)$

$109(26.9)$

$75(27.8)$

$34(25.2)$

Trying to get

pregnant $^{\dagger}$

Yes

$102(25.2)$

$303(74.8)$

45 (16.7)

$225(83.3)$

$57(42.2)$

$<0.0001$

No

Ever pregnant (at

study initiation)

Yes

255 (63.0)

$150(37.0)$

$165(61.1)$

105 (38.9)

$90(66.7)$

0.28

${ }^{*}$ Chi-square P-values were calculated by comparing women who did not have a pregnancy $(\mathrm{N}=270)$ with women who did have a pregnancy $(\mathrm{N}=135)$. Missing values were not included in these calculations and percentages reflect non-missing data †At baseline

${ }^{\ddagger}$ Mean over duration of study 
Table 3: Characteristics of Pregnant Women in the Mount Sinai Study of Women Office Workers

\begin{tabular}{|c|c|c|c|}
\hline & $\begin{array}{l}\text { Women } \mathrm{N}(\%) \\
\text { Live birth } \\
(\mathrm{N}=119 \text { women })\end{array}$ & $\begin{array}{c}\text { Women N (\%) } \\
\text { Spontaneous Abortion } \\
(\mathrm{N}=40 \text { women })\end{array}$ & $\begin{array}{l}\text { Chi Square } \\
\text { P-value * }\end{array}$ \\
\hline \multicolumn{4}{|c|}{ (14 ro mothen } \\
\hline $19-24$ & $8(6.7)$ & $3(7.5)$ & 0.14 \\
\hline $25-29$ & $48(40.3)$ & $8(20.0)$ & \\
\hline $30-34$ & $44(40.0)$ & $20(50.0)$ & \\
\hline $35-41$ & $19(16.0)$ & $9(22.5)$ & \\
\hline \multicolumn{4}{|l|}{ Body mass index ${ }^{\dagger}$} \\
\hline$<20$ & $21(17.7)$ & $8(20.0)$ & 0.18 \\
\hline $20-25$ & $70(58.8)$ & $18(45.0)$ & \\
\hline $25.1-30$ & $18(15.1)$ & $12(30.0)$ & \\
\hline$>30$ & $10(8.4)$ & $2(5.0)$ & \\
\hline \multicolumn{4}{|l|}{ Race $^{\dagger}$} \\
\hline White & $96(80.7)$ & $38(95.0)$ & 0.10 \\
\hline Black & $16(13.5)$ & $1(2.5)$ & \\
\hline Other & $7(5.8)$ & $1(2.5)$ & \\
\hline \multicolumn{4}{|l|}{ Ethnicity $^{\dagger}$} \\
\hline Non-Hispanic & $114(97.4)$ & $39(97.5)$ & 0.98 \\
\hline Hispanic & $3(2.6)$ & $1(2.50)$ & \\
\hline Missing & 2 & ----- & \\
\hline \multicolumn{4}{|l|}{ Marital status $^{\dagger}$} \\
\hline Married & $19(16.0)$ & $6(15.0)$ & 0.50 \\
\hline Single (never married) & $98(82.4)$ & $32(80.0)$ & \\
\hline $\begin{array}{l}\text { Divorced/separated/ } \\
\text { widowed }\end{array}$ & $2(1.6)$ & $2(5.0)$ & \\
\hline \multicolumn{4}{|l|}{ Highest education $^{\dagger}$} \\
\hline High school or less/ Tech school & $26(21.8)$ & $10(25.0)$ & 0.84 \\
\hline Some college & $34(28.6)$ & $11(27.5)$ & \\
\hline College graduate & $34(28.6)$ & $13(32.5)$ & \\
\hline Graduate school & $25(21.0)$ & $6(15.0)$ & \\
\hline \multicolumn{4}{|l|}{ Smoking status ${ }^{\dagger}$} \\
\hline Never & $57(47.9)$ & $20(50.0)$ & 0.82 \\
\hline Former & $40(33.6)$ & $9(22.5)$ & \\
\hline Current & $22(18.5)$ & $11(27.5)$ & \\
\hline \multicolumn{4}{|l|}{$\begin{array}{l}\text { Cigarettes smoked - preconception } \\
\text { (per day) }\end{array}$} \\
\hline 0 cigarettes & $83(69.8)$ & $25(62.5)$ & 0.34 \\
\hline $1-9$ cigarettes & $21(17.6)$ & $12(30.0)$ & \\
\hline 10-19 cigarettes & $9(7.6)$ & $1(2.50)$ & \\
\hline $20+$ cigarettes & $6(5.0)$ & $2(5.00)$ & \\
\hline \multicolumn{4}{|l|}{$\begin{array}{l}\text { Alcohol consumption-preconception } \\
\text { (per day) }\end{array}$} \\
\hline 0 drink & $20(16.8)$ & $4(10.0)$ & 0.01 \\
\hline$\leq 1$ drink & $92(77.3)$ & $27(67.5)$ & \\
\hline$>1$ drinks & $7(5.9)$ & $9(22.5)$ & \\
\hline
\end{tabular}


Frequency of unprotected

intercourse during ovulatory

window ${ }^{*}$

0 times

$\leq 1$ time

1 to 4 times

$>4$ times

Stress - scale from 1 (least stress) to

4 (most stress)*

$1^{\text {st }}$ quartile $(<1.57)$

$2^{\text {nd }}$ quartile (1.57-1.92)

$3^{\text {rd }}$ quartile $(1.93-2.24)$

$4^{\text {th }}$ quartile $(>2.24)$

Trying to get pregnant ${ }^{\dagger}$

Yes

No

Missing

Ever pregnant (at study initiation)

Yes

No
$16(13.4)$

$15(12.6)$

$46(38.7)$

$42(35.3)$

$30(25.3)$

$28(23.5)$

$28(23.5)$

$33(27.7)$

$48(47.5)$

$53(52.5)$

18

$78(65.5)$

$41(34.5)$
$2(5.0)$

0.33

$8(20.0)$

$17(42.5)$

$13(32.5)$

$9(22.5)$

0.32

$12(30.0)$

$13(32.5)$

$6(15.0)$

$10(26.3)$

$28(73.7)$

2

$28(70.0)$

$12(30.0)$

0.11

${ }^{*}$ Chi-square $\mathrm{P}$-values were calculated by comparing women with live births $(\mathrm{N}=119)$ with women with spontaneous abortions $(\mathrm{N}=40)$. Missing values were not included in these calculations and percentages reflect non-missing data ${ }^{\dagger}$ At baseline

Mean over duration of study 
Table 4: Multivariable model for fecundability for first pregnancies"

\begin{tabular}{|c|c|c|c|c|c|c|c|c|c|}
\hline & \multicolumn{3}{|c|}{$\begin{array}{c}\text { Mean stress over the cycle } \\
\mathrm{N}=405 \text { women } \\
\text { (2741 cycles, } 135 \text { pregnancies) }\end{array}$} & \multicolumn{3}{|c|}{$\begin{array}{l}\text { Mean stress during ovulatory window } \\
\text { N=399 women } \\
\text { (2465 cycles, } 104 \text { pregnancies })\end{array}$} & \multicolumn{3}{|c|}{$\begin{array}{l}\text { Mean stress during implantation window } \\
\text { N=397 women } \\
\text { (2567 cycles, } 104 \text { pregnancies })\end{array}$} \\
\hline & FOR $^{\dagger}$ & $95 \%$ CI & P-value & FOR & $95 \%$ CI & P-value & FOR & $95 \%$ CI & P-value \\
\hline Stress $^{*}$ & 0.76 & $(0.57-1.01)$ & 0.06 & 0.65 & $(0.49-0.87)$ & 0.003 & 0.86 & $(0.65-1.13)$ & 0.28 \\
\hline \multicolumn{10}{|l|}{$\begin{array}{l}\text { Adjusted covariates } \\
\text { Age (years) }{ }^{\S}\end{array}$} \\
\hline $1(19-24)$ & reference & & & reference & & & reference & & \\
\hline $2(25-29)$ & 0.71 & $(0.39-1.31)$ & 0.27 & 0.76 & $(0.38-1.51)$ & 0.43 & 0.67 & $(0.34-1.31)$ & 0.24 \\
\hline $3(30-34)$ & 0.74 & $(0.40-1.38)$ & 0.34 & 0.79 & $(0.40-1.59)$ & 0.51 & 0.75 & $(0.38-1.50)$ & 0.42 \\
\hline $4(35-41)$ & 0.37 & $(0.19-0.74)$ & 0.005 & 0.42 & $(0.19-0.92)$ & 0.03 & 0.40 & $(0.19-0.85)$ & 0.02 \\
\hline \multicolumn{10}{|l|}{ BMI $\left(\mathrm{kg} / \mathrm{m}^{2}\right)^{\S}$} \\
\hline $1(<20)$ & reference & & & reference & & & reference & & \\
\hline $2(20-25)$ & 0.73 & $(0.47-1.13)$ & 0.16 & 0.69 & $(0.42-1.14)$ & 0.15 & 0.64 & $(0.39-1.03)$ & 0.07 \\
\hline $3(26-30)$ & 0.61 & $(0.35-1.05)$ & 0.07 & 0.60 & $(0.33-1.12)$ & 0.11 & 0.52 & $(0.28-0.97)$ & 0.04 \\
\hline $4(>30)$ & 0.33 & $(0.16-0.68)$ & 0.003 & 0.29 & $(0.13-0.67)$ & 0.004 & 0.31 & $(0.14-0.68)$ & 0.004 \\
\hline $\begin{array}{l}\text { Avg. alcohol } \\
\text { (drinks per day) }\end{array}$ & 0.93 & $(0.89-0.98)$ & 0.004 & 0.94 & $(0.89-0.99)$ & 0.02 & 0.94 & $(0.89-0.99)$ & 0.03 \\
\hline $\begin{array}{l}\text { Unprotected } \\
\text { intercourse } \\
\text { in ovulatory window }\end{array}$ & 1.50 & $(1.29-1.76)$ & $<0.0001$ & 1.52 & $(1.26-1.83)$ & $<0.0001$ & 1.51 & $(1.25-1.81)$ & $<0.0001$ \\
\hline Pregnancy intention ${ }^{\S}$ & & & & & & & & & \\
\hline $\begin{array}{l}\text { No } \\
\text { Yes }\end{array}$ & $\begin{array}{l}\text { reference } \\
1.35\end{array}$ & $(0.91-2.00)$ & 0.14 & $\begin{array}{l}\text { reference } \\
1.46\end{array}$ & $(0.93-2.29)$ & 0.10 & $\begin{array}{l}\text { reference } \\
1.26\end{array}$ & $(0.81-1.97)$ & 0.31 \\
\hline
\end{tabular}

${ }^{*}$ First pregnancies in study

${ }^{\dagger}$ FOR: Fecundability odds ratio

"During study

${ }^{\S}$ At baseline 
Table 5: Multivariable model for fecundability for first pregnancies*

Mean stress during ovulatory window relative to woman average stress

$\mathrm{N}=399$ women ( 2465 cycles, 104 pregnancies)

\begin{tabular}{|c|c|c|c|}
\hline & OR & $95 \%$ CI & P-value \\
\hline Stress $^{\dagger}$ & 0.70 & $(0.47-1.05)$ & 0.08 \\
\hline \multicolumn{4}{|l|}{ Adjusted covariates } \\
\hline \multicolumn{4}{|l|}{ Age (years) } \\
\hline $1(19-24)$ & reference & & \\
\hline $2(25-29)$ & 0.66 & $(0.35-1.28)$ & 0.22 \\
\hline $3(30-34)$ & 0.70 & $(0.36-1.36)$ & 0.29 \\
\hline $4(35-41)$ & 0.37 & $(0.17-0.78)$ & 0.010 \\
\hline \multicolumn{4}{|l|}{ BMI $\left(\mathbf{k g} / \mathbf{m}^{2}\right)^{\ddagger}$} \\
\hline $1(<20)$ & reference & & \\
\hline $2(20-25)$ & 0.65 & $(0.40-1.06)$ & 0.08 \\
\hline $3(26-30)$ & 0.55 & $(0.30-1.02)$ & 0.06 \\
\hline $4(>30)$ & 0.26 & $(0.11-0.61)$ & 0.002 \\
\hline $\begin{array}{l}\text { Avg. alcohol } \\
\text { (drinks per day) }^{\dagger}\end{array}$ & 0.94 & $(0.89-0.99)$ & 0.02 \\
\hline $\begin{array}{l}\text { Unprotected intercourse } \\
\text { during ovulatory window }{ }^{\dagger}\end{array}$ & 1.53 & $(1.27-1.84)$ & $<0.0001$ \\
\hline \multicolumn{4}{|l|}{ Pregnancy intention } \\
\hline No & reference & & \\
\hline Yes & 1.40 & $(0.89-2.18)$ & 0.14 \\
\hline
\end{tabular}


Table 6: Multivariable model for spontaneous abortion for first pregnancies*

\begin{tabular}{|c|c|c|c|c|c|c|c|c|c|}
\hline & \multicolumn{3}{|c|}{$\begin{array}{l}\text { Mean stress over the cycle } \\
\mathrm{N}=139 \text { pregnancies }(38 \mathrm{SA})\end{array}$} & \multicolumn{3}{|c|}{$\begin{array}{l}\text { Mean stress during ovulatory window } \\
\quad \mathrm{N}=105 \text { pregnancies ( } 33 \mathrm{SA} \text { ) }\end{array}$} & \multicolumn{3}{|c|}{$\begin{array}{l}\text { Mean stress during implantation window } \\
\mathrm{N}=106 \text { pregnancies ( } 35 \mathrm{SA})\end{array}$} \\
\hline Stress $^{\dagger}$ & $\begin{array}{c}\text { OR } \\
0.86\end{array}$ & $\begin{array}{l}\mathbf{9 5 \%} \text { CI } \\
(0.43-1.71)\end{array}$ & $\begin{array}{l}\text { P-value } \\
0.66\end{array}$ & $\begin{array}{l}\text { OR } \\
0.64\end{array}$ & $\begin{array}{l}\mathbf{9 5 \%} \text { CI } \\
(0.34-1.20)\end{array}$ & $\begin{array}{l}\text { P-value } \\
0.16\end{array}$ & $\begin{array}{l}\text { OR } \\
0.84\end{array}$ & $\begin{array}{l}\mathbf{9 5 \%} \text { CI } \\
(0.49-1.43)\end{array}$ & $\begin{array}{l}\text { P-value } \\
0.51\end{array}$ \\
\hline $\begin{array}{l}\text { Avg. alcohol } \\
\text { (drinks per day) }\end{array}$ & 1.05 & $(0.97-1.14)$ & 0.22 & 1.02 & $(0.93-1.11)$ & 0.74 & 1.02 & $(0.94-1.12)$ & 0.61 \\
\hline $\begin{array}{l}\text { Pregnancy } \\
\text { intention } \\
\text { No } \\
\text { Yes }\end{array}$ & $\begin{array}{l}\text { reference } \\
0.41\end{array}$ & $(0.18-0.96)$ & 0.04 & $\begin{array}{l}\text { reference } \\
0.43\end{array}$ & $(0.18-1.07)$ & 0.07 & $\begin{array}{l}\text { reference } \\
0.43\end{array}$ & $(0.18-1.04)$ & 0.06 \\
\hline
\end{tabular}

\footnotetext{
First pregnancies during study

${ }^{\dagger}$ During study

$\star$ At baseline
} 
Table 7: Multivariable model for spontaneous abortion for first pregnancies*

\begin{tabular}{lccl}
\hline & \multicolumn{3}{c}{ Mean stress during cycle relative to woman average stress } \\
& $\mathrm{N}=159$ pregnancies (40 SA) \\
\hline & OR & $\mathbf{9 5 \%}$ CI & P-value \\
Stress $^{\dagger}$ & 2.52 & $(1.17-5.43)$ & 0.01
\end{tabular}

Adjusted covariates

$\begin{array}{llll}\text { Age }^{*} & & & \\ & & & \\ \text { Alcohol cat } & 1.08 & (0.98-1.18) & \\ \text { (drinks per day) }^{\dagger} & & & \\ \mathbf{0} & \text { reference } & & \\ \mathbf{1} & 1.27 & (0.39-4.16) & 0.70 \\ \mathbf{2} & 5.80 & (1.28-26.4) & 0.03\end{array}$

${ }^{*}$ First pregnancies during study

${ }^{\dagger}$ During study

* At baseline 


\section{DISCUSSION}

\section{Main findings on fecundability}

This is the first prospective cohort study to find an association between selfreported stress and both fecundability and spontaneous abortion. Daily self-reported stress prior to conception significantly reduces fecundability among a cohort of women office workers. Out of a total of 487 women, there were 82 women with missing data for relevant covariates. Chi-square test revealed that these women were not representative for specific covariates. Nevertheless, there was not a difference in likelihood of pregnancy comparing the 82 women vs. the 405 ; therefore, the exclusion of these 82 women from the fecundability analysis should not have resulted in any selection bias.

Women with higher self-reported stress during the ovulatory window had a $35 \%$ decrease in fecundability compared to women with lower stress. This finding was still statistically significant after restricting to cycles with at least $90 \%$ complete data $(\mathrm{FOR}=0.61, \mathrm{P}=0.01)$. Higher average stress during the implantation window was associated with decreased fecundability, but not significantly. These findings are in general agreement with earlier studies however with variations in study population and stress ascertainment (Hjollund et al. 2000, Louis et al. 2011, Lynch et al. 2014).

\section{Previous literature}

To date only a handful of prospective studies have rigorously examined the 
unclear association between stress and fecundability. However, in each one of these studies stress was ascertained in a different manner. One study solely examined stress biomarkers, i.e. salivary alpha-amylase and cortisol (Louis et al. 2011), while another study assessed both stress biomarkers and a psychosocial questionnaire (Lynch et al. 2012, Lynch et al. 2014). All of these studies were conducted pre-conceptionally, however with shorter follow-up periods (6 cycles or until pregnant) (Hjollund et al. 1999, Louis et al. 2011, Lynch et al. 2012).The one prospective study that did not assess stress biomarkers examined psychological distress scores (scored 0 (low stress) to 3 (high stress)) from a questionnaire, but this was only administered once during each cycle (Hjollund et al. 1999).

The main element that sets the current study apart from previous studies is the daily collection of stress. Two studies collected their samples on day 6 of each cycle (Louis et al. 2011, Lynch et al. 2012) while another study collected data on day 21 of each cycle (Hjollund et al. 1999). By collecting daily diaries of stress, we were able to track how stress levels changed throughout important windows of the menstrual cycle, a limitation of the Lynch et al. (2014) study. The recent findings from the Lynch et al. (2014) study has received a lot of attention from the media and their results were most similar to the current study with a $29 \%$ reduction in fecundability for women with higher salivary alpha-amylase levels. Although they had the same 12 cycle follow-up period as the current study, they collected samples only once in the morning of the first menses during the cycle. A self-administered questionnaire was provided to ascertain covariate information including one daily stress question, but they did not evaluate self-reported stress in the analysis (Lynch et al. 2014). In addition, they did not adjust for frequency of 
intercourse anywhere in the analysis.

\section{Possible mechanisms}

Our findings may be consistent with the imbalance in immune-endocrine interaction theory. Following the initial stress response from the sympathetic nervous system, the HPA axis is stimulated and cortisol is released. In cases of chronic stress, the HPA axis can be over-activated thereby eliciting an autoimmune state unfavorable for successful implantation (Makrigiannakis et al. 2001). Another possible mechanism is the delay or inhibition of the FSH and the LH surge. A decrease in FSH impairs proper development of the follicle, which can then affect the levels of progesterone in the luteinized follicle after ovulation (Wang et al. 2004). Progesterone is a vital hormone necessary during the preparation and development of the endometrium. When glucocorticoid levels are high in the endometrium, it delays the LH peak that pinpoints ovulation and then the beginning of the luteal phase (Nepomnaschy et al. 2004, Nakamura et al. 2008). When the luteal phase is shortened, progesterone availability is limited and there exists an insufficient amount of progesterone for proper implantation.

A second analysis revealed similar results to the main analysis with a $30 \%$ reduction in fecundability when the mean stress during the ovulatory window was higher than each woman"s individual mean for stress, adjusting for age, alcohol intake, frequency of unprotected intercourse, pregnancy intention, and BMI. To our knowledge, no other study has conducted an analysis on fecundability using a relative measure of stress. During the ovulatory window, ovarian function can be compromised in numerous ways including lack of matured follicles, disruption in signaling between gonadotropins 
and receptors on the ovary, and interruption in vital steroids release (Berga 2008). Gonadotropin releasing hormone $(\mathrm{GnRH})$ is regulated by catecholamines, i.e. dopamine, endogenous opioids, and glucocorticoids (Kalra et al. 1984). Increasing levels of CRH and glucocorticoids greatly suppresses the normal function of $\mathrm{GnRH}$, consequently causing anovulation (Berga 2008).

\section{Main findings on spontaneous abortion}

We found a significant association between self-reported stress and the risk of spontaneous abortion when we used a relative measure of stress (evaluating when a woman was more stressed in a particular cycle compared to her individual mean stress.) This analysis differed from another analysis where we evaluated the individual effects of self-reported stress across windows in the menstrual cycle on the risk of spontaneous abortion. No association was found possibly due to the smaller sample size and that $60 \%$ of the study population had lower stress overall.

\section{Possible mechanisms}

The findings on relative stress may be due to over-stimulation of CRH. Higher levels of CRH inhibit normal secretion of pituitary luteinizing hormone and progesterone (Magiakou et al. 1997). If appropriate levels of progesterone are not reached, the uterine environment may be hostile to the growing embryo. Arck et al. (2008) found a direct interaction between older maternal age and low progesterone levels. They concluded that maternal age could be a mediator in the pathway between stress and spontaneous abortion. However, this particular interaction was not observed for the current study. 


\section{Previous literature}

The few studies that have found an increased risk of spontaneous abortion ascertained stress in a different method by examining various biomarkers of stress. One study found a positive association with higher levels of cortisol. Although they obtained samples three times a week for a follow-up period of 12 months, this was in a very small Mayan population whose characteristics differ greatly from the current study (Nepomnaschy et al. 2006). Another study examined progesterone and CRH levels along with psychosocial distress scores from a questionnaire. The sample population was much larger in this study $(\mathrm{N}=864)$, however they gathered data only once during the entire study (Arck et al. 2008).

To date only one other study has used the self-reported measure of stress. Hjollund et al. (2000) examined a cohort of 430 women who recorded stress on a 4-point scale in a daily diary. Similar to our study, they conducted the analysis by comparing each woman"s average stress during the cycle to her individual mean (Hjollund et al. 2000)(Note: in comparison to using the average stress during the ovulatory window for the secondary fecundability analysis, we used the average stress over the cycle because spontaneous abortion does not occur till after conception.)Findings from the Hjollund et al. (2000) study were consistent with the current study, except smaller numbers in some categories led to wider confidence intervals. Although pregnancy intention has had some literary spotlight with regard to this association (Maconochie et al. 2007), we did not include it in this particular analysis; in an attempt to get the most parsimonious combination of variables, we excluded covariates that did not change the stress estimate by $10 \%$ (Jewell 2004). Nevertheless, the Hjollund et al. (2000) paper had some 
distinguishable variations from the current study. Data collection was only on day 21 of each cycle, the short follow-up period of 6 cycles (or until pregnant), and daily stress recordings were restricted to physical strain and external demands scores(Hjollund et al. 2000).

\section{Study strengths}

There are several strengths in this cohort study including the three phases of the menstrual cycle during which stress was ascertained. Past studies have discrepancies in their findings possibly due to the timing of stress data collection/ Many have limited stress collection to the follicular phase (Wang et al. 2004, Louis et al. 2011, Lynch et al. 2012) while others restricted it to the luteal phase (Hjollund et al. 2000). By examining time windows in both the follicular and luteal phases, we were able to assess the effects of varying stress levels across major time-points in the menstrual cycle.

Furthermore daily data on numerous socio-behavioral and lifestyle factors were collected. This reduced the likelihood of confounding by evaluating for all relevant covariates based on prior literature. However, due to a relatively small sample size, we did not include all covariates in the model and used two methods to reduce the number of covariates to the most parsimonious reasonable model.

One of the greatest strengths of this study was obtaining stress data prior to conception. The women in our study were instructed to keep a daily diary of their stress levels until pregnant. This eliminates any recall bias created by the couple in being aware of the success of the pregnancy attempt and the pregnancy outcome. Nevertheless, some women recorded stress for only a few days out of the cycle. Therefore we did a 
sensitivity analysis accounting for only those women who had at least $90 \%$ stress

recordings during the cycle. The strength of the sample size still persisted $(\mathrm{N}=372)$ with only an $8 \%$ loss in participants and the results were -- in fact, they were actually stronger in some cases than the findings using the entire dataset.

With regard to generalizability, approximately $30 \%$ of the pregnant women in our study population had a spontaneous abortion indicating that this subset was representative of the general population "s prevalence for spontaneous abortion(Wilcox et al. 1988, Wainstock et al. 2013).

\section{Study limitations}

Concerning limitations of this study, we were unable to obtain a more comprehensive ascertainment of the stress exposure. We did not measure biomarkers of stress. Stress was only self-reported, measured on a categorical scale from 1 to 4 . Since stress exposure was not the main objective under MSSWOW, additional questions regarding stress such as stress at work, physical strain, or psychosocial stress were not provided to the participants. The day of ovulation was ascertained through estimation using the Knaus-Ogino method since no monitor was used to assess LH surges during the woman's menstrual cycle(Knaus 1929, Ogino 1930). This method of estimation has been used in a few studies regarding the same exposure of interest (Hjollund et al. 2000, Louis et al. 2011). Recurrent spontaneous abortion has been well known to be a significant predictor of this adverse pregnancy outcome, however we were unable to account for prior pregnancy losses because the dataset did not contain this information. Furthermore, our analyses on multiple pregnancies were not completely correct because we did not 
account for the correlation between successive pregnancies. Finally, sample size was limited for some variables due to missing data on covariates. 


\section{CONCLUSION}

Our findings support a significant reduction in fecundability especially during the fertile window for women experiencing high levels of stress prior to conception. Furthermore, our study has revealed a significantly higher risk of spontaneous abortion for women whose average stress during the cycle was higher than their individual mean. While these findings do not definitively settle the controversy on stress and female reproductive failure, it certainly progresses the research movement with strong evidence. This investigation emphasizes the need to expand research on the individual adverse effects of stress on pregnancy outcomes during conception, implantation and pregnancy maintenance. Future research should aim to evaluate associations between stress perception, stress biomarkers, and stress-related genetic polymorphisms on adverse pregnancy outcomes, as there still remains a vast amount to be learned about the underlying causal mechanisms at play. This research emphasizes the importance of stress prevention and alleviation before and during pregnancy. Numerous methods for reducing stress in the trying and expecting mother have been pushed to movement but are still not in full practice. Stresses of daily life can take an unexpected toll on both mind and body. Therefore it is vital that methods to reduce stress are implemented and encouraged in the community and physician offices to minimize the overall stress placed on the expecting mother. This is an action that can be taken today to provide a better life and healthier pregnancy for expectant mothers around the world. 


\section{REFERENCES}

Anderheim, L., H. Holter, C. Bergh and A. Moller (2005). "Does psychological stress affect the outcome of in vitro fertilization?" Human reproduction20(10): 2969-2975.

Arck, P. C., M. Rucke, M. Rose, J. Szekeres-Bartho, A. J. Douglas, M. Pritsch, et al. (2008). "Early risk factors for miscarriage: a prospective cohort study in pregnant women." Reproductive biomedicine online17(1): 101-113.

Baird, D. D., A. J. Wilcox and C. R. Weinberg (1986). "Use of time to pregnancy to study environmental exposures." American journal of epidemiology124(3): 470-480.

Baum, A. and D. Polsusnzy (1999). "Health Psychology: Mapping Biobehavioral Contributions to Health and Illness." Annual Review of Psychology50: 137-163.

Berga, S. L. (2008). "The brain and the menstrual cycle." Gynecological endocrinology: the official journal of the International Society of Gynecological Endocrinology24(10): 537.

Bonen, A. (1994). "Exercise-induced menstrual cycle changes. A functional, temporary adaptation to metabolic stress." Sports medicine17(6): 373-392.

Bosch, J. A., H. S. Brand, T. J. Ligtenberg, B. Bermond, J. Hoogstraten and A. V. Nieuw Amerongen (1996). "Psychological stress as a determinant of protein levels and salivary-induced aggregation of Streptococcus gordonii in human whole saliva." Psychosomatic medicine58(4): 374-382.

Catherino, W. H. (2011). "Stress relief to augment fertility: the pressure mounts." 
Fertility and sterility95(8): 2462-2463.

Cramer, D. W. and L. A. Wise (2000). "The epidemiology of recurrent pregnancy loss." Seminars in reproductive medicine 18(4): 331-339.

de Liz, T. M. and B. Strauss (2005). "Differential efficacy of group and individual/couple psychotherapy with infertile patients." Human reproduction 20(5): 1324-1332.

Domar, A. D., D. Clapp, E. A. Slawsby, J. Dusek, B. Kessel and M. Freizinger (2000). "Impact of group psychological interventions on pregnancy rates in infertile women." Fertility and sterility 73(4): 805-811.

Domar, A. D., K. L. Rooney, B. Wiegand, E. J. Orav, M. M. Alper, B. M. Berger, et al. (2011). "Impact of a group mind/body intervention on pregnancy rates in IVF patients." Fertility and sterility95(7): 2269-2273.

Gatti, R., G. Antonelli, M. Prearo, P. Spinella, E. Cappellin and E. F. De Palo (2009). "Cortisol assays and diagnostic laboratory procedures in human biological fluids." Clinical biochemistry42(12): 1205-1217.

Ghanem, M. E., E. E. Sadek, L. A. Elboghdady, A. S. Helal, A. Gamal, A. Eldiasty, et al. (2009). "The effect of luteal phase support protocol on cycle outcome and luteal phase hormone profile in long agonist protocol intracytoplasmic sperm injection cycles: a randomized clinical trial." Fertility and sterility92(2): 486-493.

Goodman, M. H. (2008). Basic Medical Endocrinology, Academic Press.

Hjollund, N. H., T. K. Jensen, J. P. Bonde, T. B. Henriksen, A. M. Andersson, H. A. Kolstad, et al. (1999). "Distress and reduced fertility: a follow-up study of firstpregnancy planners." Fertility and sterility 72(1): 47-53.

Hjollund, N. H., T. K. Jensen, J. P. Bonde, T. B. Henriksen, A. M. Andersson, H. A. 
Kolstad, et al. (2000). "Spontaneous abortion and physical strain around implantation: a follow-up study of first-pregnancy planners." Epidemiology11(1): 18-23.

Hosmer, D. W. and S. Lemeshow (2000). Applied Logistic Regression. New York, John Wiley \& Sons.

Jensen, T. K., N. H. Hjollund, T. B. Henriksen, T. Scheike, H. Kolstad, A. Giwercman, et al. (1998). "Does moderate alcohol consumption affect fertility? Follow up study among couples planning first pregnancy." Bmj317(7157): 505-510.

Jewell, N. P. (2004). Statistics for Epidemiology. Boca Raton, Florida, Chapman \& Hall: 246-254.

Kalra, S. P. and P. S. Kalra (1984). "Opioid-adrenergic-steroid connection in regulation of luteinizing hormone secretion in the rat." Neuroendocrinology38(5): 418-426.

Klonoff-Cohen, H., E. Chu, L. Natarajan and W. Sieber (2001). "A prospective study of stress among women undergoing in vitro fertilization or gamete intrafallopian transfer." Fertility and sterility76(4): 675-687.

Knaus, H. (1929). "Eine neue Methods zur Betimmung des Ovulationstermines." Zentralbl F Gynak53.

Louis, G. M., K. J. Lum, R. Sundaram, Z. Chen, S. Kim, C. D. Lynch, et al. (2011). "Stress reduces conception probabilities across the fertile window: evidence in support of relaxation." Fertility and sterility95(7): 2184-2189.

Lynch, C. D., R. Sundaram, G. M. Buck Louis, K. J. Lum and C. Pyper (2012). "Are increased levels of self-reported psychosocial stress, anxiety, and depression associated with fecundity?" Fertility and sterility 98(2): 453-458.

Lynch, C. D., R. Sundaram, J. M. Maisog, A. M. Sweeney and G. M. Buck Louis (2014). 
"Preconception stress increases the risk of infertility: results from a couple-based prospective cohort study--the LIFE study." Human reproduction29(5): 1067-1075. Maconochie, N., P. Doyle, S. Prior and R. Simmons (2007). "Risk factors for first trimester miscarriage--results from a UK-population-based case-control study." BJOG : an international journal of obstetrics and gynaecology114(2): 170-186.

Magiakou, M. A., G. Mastorakos, E. Webster and G. P. Chrousos (1997). "The hypothalamic-pituitary-adrenal axis and the female reproductive system." Annals of the New York Academy of Sciences816: 42-56.

Mai, F. M. (1971). "Conception after adoption: an open question." Psychosomatic medicine33(6): 509-514.

Makrigiannakis, A., E. Zoumakis, S. Kalantaridou, C. Coutifaris, A. N. Margioris, G. Coukos, et al. (2001). "Corticotropin-releasing hormone promotes blastocyst implantation and early maternal tolerance." Nature immunology2(11): 1018-1024.

Malassine, A. and L. Cronier (2002). "Hormones and human trophoblast differentiation: a review." Endocrine 19(1): 3-11.

Marcus, M. and F. Gerr (1996). "Upper extremity musculoskeletal symptoms among female office workers: associations with video display terminal use and occupational psychosocial stressors." American journal of industrial medicine29(2): 161-170.

Marcus, M., R. McChesney, A. Golden and P. Landrigan (2000). "Video display terminals and miscarriage." Journal of the American Medical Women's Association55(2): 84-88, 105.

Nakamura, H., T. Kimura, K. Ogita, T. Nakamura, M. Takemura, K. Shimoya, et al. (2004). "NF-kappaB activation at implantation window of the mouse uterus." 
American journal of reproductive immunology51(1): 16-21.

Nakamura, K., S. Sheps and P. C. Arck (2008). "Stress and reproductive failure: past notions, present insights and future directions." Journal of assisted reproduction and genetics 25(2-3): 47-62.

Nater, U. M., N. Rohleder, J. Gaab, S. Berger, A. Jud, C. Kirschbaum, et al. (2005). "Human salivary alpha-amylase reactivity in a psychosocial stress paradigm." International journal of psychophysiology : official journal of the International Organization of Psychophysiology55(3): 333-342.

Nelson, D. B., J. A. Grisso, M. M. Joffe, C. Brensinger, L. Shaw and E. Datner (2003). "Does stress influence early pregnancy loss?" Annals of epidemiology13(4): 223-229.

Nepomnaschy, P. A., K. Welch, D. McConnell, B. I. Strassmann and B. G. England (2004). "Stress and female reproductive function: a study of daily variations in cortisol, gonadotrophins, and gonadal steroids in a rural Mayan population." American journal of human biology: the official journal of the Human Biology Council16(5): 523-532.

Nepomnaschy, P. A., K. B. Welch, D. S. McConnell, B. S. Low, B. I. Strassmann and B. G. England (2006). "Cortisol levels and very early pregnancy loss in humans." Proceedings of the National Academy of Sciences of the United States of America 103(10): 3938-3942.

Nierop, A., A. Bratsikas, A. Klinkenberg, U. M. Nater, R. Zimmermann and U. Ehlert (2006). "Prolonged salivary cortisol recovery in second-trimester pregnant women and attenuated salivary alpha-amylase responses to psychosocial stress in human pregnancy." The Journal of clinical endocrinology and metabolism91(4): 1329-1335. 
Ogino, K. (1930). "Ovulationstermin und Konzeptionstermin." Zentralbl F Gynak54: 464-479.

Parker, V. J. and A. J. Douglas (2010). "Stress in early pregnancy: maternal neuroendocrine-immune responses and effects." Journal of reproductive immunology85(1): 86-92.

Pruessner, J. C., O. T. Wolf, D. H. Hellhammer, A. Buske-Kirschbaum, K. von Auer, S. Jobst, et al. (1997). "Free cortisol levels after awakening: a reliable biological marker for the assessment of adrenocortical activity." Life sciences61(26): 2539-2549.

Rasch, V. (2003). "Cigarette, alcohol, and caffeine consumption: risk factors for spontaneous abortion." Acta obstetricia et gynecologica Scandinavica82(2): 182-188.

Razieh, D. F., A. R. Maryam and T. Nasim (2009). "Beneficial effect of luteal-phase gonadotropin-releasing hormone agonist administration on implantation rate after intracytoplasmic sperm injection." Taiwanese journal of obstetrics \& gynecology48(3): 245-248.

Rock, J., C. Tietze and H. B. McLaughlin (1965). "Effect of Adoption on Infertility." Fertility and sterility16: 305-312.

Salacz, P., G. Csukly, J. Haller and S. Valent (2012). "Association between subjective feelings of distress, plasma cortisol, anxiety, and depression in pregnant women." European journal of obstetrics, gynecology, and reproductive biology165(2): 225230.

Scheike, T. H. and N. Keiding (2006). "Design and analysis of time-to-pregnancy." Statistical methods in medical research15(2): 127-140.

Schmidt-Sarosi, C., L. B. Schwartz, J. Lublin, D. Kaplan-Grazi, P. Sarosi and M. A. Perle 
(1998). "Chromosomal analysis of early fetal losses in relation to transvaginal ultrasonographic detection of fetal heart motion after infertility." Fertility and sterility69(2): 274-277.

Schulz, P., C. Kirschbaum, J. C. Pruessner and D. Hellhammer (1998). "Increased free cortisol secretion after awakening in chronically stressed individuals due to work overload." Stress Med.14: 91-97.

Skosnik, P. D., R. T. Chatterton, Jr., T. Swisher and S. Park (2000). "Modulation of attentional inhibition by norepinephrine and cortisol after psychological stress." International journal of psychophysiology : official journal of the International Organization of Psychophysiology36(1): 59-68.

Small, C. M., A. K. Manatunga, M. Klein, H. S. Feigelson, C. E. Dominguez, R. McChesney, et al. (2006). "Menstrual cycle characteristics: associations with fertility and spontaneous abortion." Epidemiology17(1): 52-60.

Stern, J. J., A. D. Dorfmann, A. J. Gutierrez-Najar, M. Cerrillo and C. B. Coulam (1996). "Frequency of abnormal karyotypes among abortuses from women with and without a history of recurrent spontaneous abortion." Fertility and sterility65(2): 250-253.

Sugiura-Ogasawara, M., T. A. Furukawa, Y. Nakano, S. Hori, K. Aoki and T. Kitamura (2002). "Depression as a potential causal factor in subsequent miscarriage in recurrent spontaneous aborters." Human reproduction17(10): 2580-2584.

Symonds, M. E., T. Stephenson, D. S. Gardner and H. Budge (2007). "Long-term effects of nutritional programming of the embryo and fetus: mechanisms and critical windows." Reproduction, fertility, and development19(1): 53-63.

Takai, N., M. Yamaguchi, T. Aragaki, K. Eto, K. Uchihashi and Y. Nishikawa (2004). 
"Effect of psychological stress on the salivary cortisol and amylase levels in healthy young adults." Archives of oral biology49(12): 963-968.

Taylor, K. C., C. M. Small, C. E. Dominguez, L. E. Murray, W. Tang, M. M. Wilson, et al. (2011). "alcohol, smoking, and caffeine in relation to fecundability, with effect modification by NAT2." Annals of epidemiology21(11): 864-872.

Torpy, D. J. and G. P. Chrousos (1996). "The three-way interactions between the hypothalamic-pituitary-adrenal and gonadal axes and the immune system." Bailliere's clinical rheumatology10(2): 181-198.

Wainstock, T., L. Lerner-Geva, S. Glasser, I. Shoham-Vardi and E. Y. Anteby (2013). "Prenatal stress and risk of spontaneous abortion." Psychosomatic medicine 75(3): $228-235$.

Wang, L., X. Wang, W. Wang, C. Chen, A. G. Ronnennberg, W. Guang, et al. (2004). "Stress and dysmenorrhoea: a population based prospective study." Occupational and environmental medicine61(12): 1021-1026.

Weir, W. C. and D. R. Weir (1966). "Adoption and subsequent conceptions." Fertility and sterility17(2): 283-288.

Wilcox, A. J., C. R. Weinberg, J. F. O'Connor, D. D. Baird, J. P. Schlatterer, R. E. Canfield, et al. (1988). "Incidence of early loss of pregnancy." The New England journal of medicine319(4): 189-194.

Wust, S., I. Federenko, D. H. Hellhammer and C. Kirschbaum (2000). "Genetic factors, perceived chronic stress, and the free cortisol response to awakening." Psychoneuroendocrinology25(7): 707-720. 
APPENDIX 
Supplemental Table 1: $\quad$ Unadjusted and adjusted estimates for fecundability for all first pregnancies ${ }^{*}$

\begin{tabular}{|c|c|c|c|c|c|c|c|c|c|c|c|c|}
\hline & \multicolumn{4}{|c|}{$\begin{array}{l}\text { Mean stress over the cycle } \\
\mathrm{N}=487 \text { women, } 3483 \text { cycles }\end{array}$} & \multicolumn{4}{|c|}{$\begin{array}{l}\text { Mean stress during the ovulatory window } \\
\mathrm{N}=476 \text { women, } 2853 \text { cycles }\end{array}$} & \multicolumn{4}{|c|}{$\begin{array}{l}\text { Mean stress during the implantation window } \\
\qquad \mathrm{N}=474 \text { women, } 2900 \text { cycles }\end{array}$} \\
\hline & $\begin{array}{l}\text { Stress } \\
\text { Estimate }\end{array}$ & $\begin{array}{l}\text { Covariate } \\
\text { Estimate }\end{array}$ & $\begin{array}{l}\text { Standard } \\
\text { Error }\end{array}$ & P-value & \begin{tabular}{|l} 
Stress \\
Estimate
\end{tabular} & $\begin{array}{l}\text { Covariate } \\
\text { Estimate }\end{array}$ & $\begin{array}{l}\text { Standard } \\
\text { Error }\end{array}$ & P-value & $\begin{array}{l}\text { Stress } \\
\text { Estimate }\end{array}$ & $\begin{array}{l}\text { Covariate } \\
\text { Estimate }\end{array}$ & $\begin{array}{l}\text { Standard } \\
\text { Error }\end{array}$ & P-value \\
\hline Unadjusted & -1.2327 & & 0.0860 & $<0.0001$ & -1.2000 & & 0.0956 & $<0.0001$ & -1.1491 & & 0.0920 & $<0.0001$ \\
\hline \multicolumn{13}{|l|}{$\begin{array}{l}\text { Adjusted } \\
\text { (one at a time) }\end{array}$} \\
\hline Age $^{\dagger}$ & -0.2728 & -0.1061 & 0.0113 & $<0.0001$ & -0.3319 & -0.1028 & 0.0124 & $<0.0001$ & -0.2544 & -0.1051 & 0.0121 & $<0.0001$ \\
\hline $\begin{array}{l}\text { Age cat } \\
\text { (years) }\end{array}$ & & & & & & & & & & & & \\
\hline $1(19-24)$ (ref) & -0.7734 & ---------- & 0.1039 & $<0.0001$ & -0.7625 & --------- & 0.1125 & $<0.0001$ & -0.6948 & --------- & 0.1083 & $<0.0001$ \\
\hline $2(25-29)$ & --------- & -1.1542 & 0.2073 & $<0.0001$ & |-------- & -1.1035 & 0.2354 & $<0.0001$ & -------- & -1.2323 & 0.2320 & $<0.0001$ \\
\hline $3(30-34)$ & --------- & -1.2277 & 0.2015 & $<0.0001$ & |--------- & -1.1776 & 0.2279 & $<0.0001$ & |--------- & -1.2377 & 0.2222 & $<0.0001$ \\
\hline $4(35-41)$ & --------- & -1.7740 & 0.2401 & $<0.0001$ & --------- & -1.7837 & 0.2741 & $<0.0001$ & |-------- & -1.8607 & 0.2669 & $<0.0001$ \\
\hline $\mathbf{B M I}^{\dagger}$ & -0.1506 & -0.0629 & 0.0154 & $<0.0001$ & -0.2418 & -0.0594 & 0.0176 & 0.0007 & -0.1471 & -0.0601 & 0.0174 & 0.0006 \\
\hline \multicolumn{13}{|l|}{$\begin{array}{l}\text { BMI cat }{ }^{\dagger} \\
\left(\mathrm{kg} / \mathrm{m}^{2}\right)\end{array}$} \\
\hline 1 (<20) (ref) & -0.0246 & --------- & 0.1194 & 0.0215 & -0.3291 & --------- & 0.1220 & 0.0070 & -0.2229 & --------- & 0.1190 & 0.0611 \\
\hline $2(20-25)$ & --------- & -0.1899 & 0.1990 & 0.3399 & |-------- & -0.2741 & 0.2267 & 0.2266 & --------- & -0.2997 & 0.2244 & 0.1816 \\
\hline $3(26-30)$ & ---------- & -0.3609 & 0.2429 & 0.1372 & |--------- & -0.2688 & 0.2693 & 0.3183 & --------- & -0.3176 & 0.2707 & 0.2407 \\
\hline $4(>30)$ & --------- & -0.8177 & 0.3196 & 0.0105 & |--------- & -1.0928 & 0.3893 & 0.0050 & --------- & -0.9875 & 0.3727 & 0.0081 \\
\hline $\begin{array}{l}\text { Avg. alcohol } \\
\text { (per day) }\end{array}$ & -0.2994 & -0.0598 & 0.0210 & 0.0044 & -0.3456 & -0.0728 & 0.0270 & 0.0071 & -0.1646 & -0.0754 & 0.0271 & 0.0054 \\
\hline \multicolumn{13}{|l|}{ Alcohol cat } \\
\hline 0 (ref) & -0.1937 & --------- & 0.1220 & 0.1123 & -0.2519 & --------- & 0.1233 & 0.0411 & -0.0475 & ---------- & 0.1219 & 0.6970 \\
\hline 1 & --------- & -0.9218 & 0.2105 & $<0.0001$ & |--------- & -0.9981 & 0.2486 & $<0.0001$ & --------- & -1.1222 & 0.2346 & $<0.0001$ \\
\hline 2 & --------- & -1.3550 & 0.3104 & $<0.0001$ & |-------- & -1.3856 & 0.3637 & $<0.0001$ & |-------- & -1.4563 & 0.3527 & $<0.0001$ \\
\hline $\begin{array}{l}\text { Avg. cigarette } \\
\text { (per day) }\end{array}$ & -0.3011 & -0.0134 & 0.0122 & 0.2733 & -0.3404 & -0.0347 & 0.0174 & 0.0454 & -0.1506 & -0.0384 & 0.0174 & 0.0278 \\
\hline \multicolumn{13}{|l|}{ Cigarette cat ${ }^{*}$} \\
\hline 0 (ref) & -0.2825 & --------- & 0.1166 & 0.0154 & -0.3266 & --------- & 0.1189 & 0.0060 & -0.1277 & ---------- & 0.1195 & 0.2851 \\
\hline 1 & --------- & -0.5250 & 0.2006 & 0.0089 & |-------- & -0.3730 & 0.2219 & 0.0928 & |--------- & -0.5276 & 0.2257 & 0.0194 \\
\hline 2 & --------- & -0.2371 & 0.3267 & 0.4681 & |-------- & -0.2829 & 0.4082 & 0.4882 & |--------- & -0.2662 & 0.3811 & 0.4849 \\
\hline 3 & --------- & -0.3429 & 0.3403 & 0.3137 & --------- & -0.9741 & 0.5228 & 0.0625 & |--------- & -1.3051 & 0.5943 & 0.0281 \\
\hline
\end{tabular}




\begin{tabular}{|c|c|c|c|c|c|c|c|c|c|c|c|c|}
\hline $\begin{array}{l}\text { Unprotected } \\
\text { intercourse }\end{array}$ & -0.3240 & 0.3213 & 0.0625 & 0.0001 & -0.3989 & 0.3378 & 0.0734 & $<0.0001$ & -0.3146 & 0.3338 & 0.0738 & $<0.0001$ \\
\hline $\begin{array}{c}\text { Pregnancy }^{\dagger} \\
\text { intention }\end{array}$ & -0.4251 & 0.4597 & 0.1641 & 0.0051 & -0.5072 & 0.5800 & 0.1874 & 0.0020 & -0.3193 & 0.4368 & 0.1867 & 0.0193 \\
\hline $\begin{array}{l}\text { Ever pregnant } \\
\text { Race }^{\dagger}\end{array}$ & -0.2794 & -0.1362 & 0.1389 & 0.3266 & -0.3151 & -0.2124 & 0.1616 & 0.1886 & -0.1175 & -0.2474 & 0.1563 & 0.1136 \\
\hline White (ref) & -1.1358 & --------- & 0.0896 & $<0.0001$ & -1.0954 & --------- & 0.0990 & $<0.0001$ & -1.0378 & --------- & 0.0950 & $<0.0001$ \\
\hline Black & --------- & -0.5004 & 0.2440 & 0.0403 & |-------- & -0.5680 & 0.2845 & 0.0459 & |-------- & -0.6190 & 0.2817 & 0.0280 \\
\hline Other & --------- & -1.3035 & 0.3686 & 0.0004 & |--------- & -1.2627 & 0.4275 & 0.0031 & --------- & -1.3575 & 0.4265 & 0.0015 \\
\hline
\end{tabular}

First pregnancy in study

At baseline 
Supplemental Table2: $\quad$ Unadjusted and adjusted estimates for fecundability for all pregnancies

\begin{tabular}{|c|c|c|c|c|c|c|c|c|c|c|c|c|}
\hline & \multicolumn{4}{|c|}{$\begin{array}{l}\text { Mean stress over the cycle } \\
N=487 \text { women, } 3503 \text { cycles }\end{array}$} & \multicolumn{4}{|c|}{$\begin{array}{l}\text { Mean stress during the ovulatory window } \\
\mathrm{N}=477 \text { women, } 2870 \text { cycles }\end{array}$} & \multicolumn{4}{|c|}{$\begin{array}{l}\text { Mean stress during the implantation window } \\
\mathrm{N}=475 \text { women, } 2917 \text { cycles }\end{array}$} \\
\hline & $\begin{array}{l}\text { Stress } \\
\text { Estimate }\end{array}$ & $\begin{array}{l}\text { Covariate } \\
\text { Estimate }\end{array}$ & $\begin{array}{l}\text { Standard } \\
\text { Error }\end{array}$ & P-value & \begin{tabular}{|l|} 
Stress \\
Estimate
\end{tabular} & $\begin{array}{l}\text { Covariate } \\
\text { Estimate }\end{array}$ & $\begin{array}{l}\text { Standard } \\
\text { Error }\end{array}$ & P-value & $\begin{array}{l}\text { Stress } \\
\text { Estimate }\end{array}$ & $\begin{array}{l}\text { Covariate } \\
\text { Estimate }\end{array}$ & $\begin{array}{l}\text { Standard } \\
\text { Error }\end{array}$ & P-value \\
\hline Unadjusted & -1.1038 & & 0.0777 & $<0.0001$ & -1.0881 & & 0.0870 & $<0.0001$ & -1.0558 & & 0.0847 & $<0.0001$ \\
\hline $\begin{array}{l}\text { Adjusted } \\
\text { (one at a time) }\end{array}$ & & & & & & & & & & & & \\
\hline $\begin{array}{l}\text { Age }{ }^{*} \\
\text { Age cat } \\
\text { (years) }\end{array}$ & -0.2301 & -0.0851 & 0.1146 & 0.0445 & -0.3236 & -0.0794 & 0.0100 & $<0.0001$ & -0.2714 & -0.0817 & 0.0099 & $<0.0001$ \\
\hline $1(19-24)$ (ref) & -0.6630 & --------- & 0.0962 & $<0.0001$ & -0.6846 & --------- & 0.1048 & $<0.0001$ & -0.6386 & --------- & 0.1016 & $<0.0001$ \\
\hline $2(25-29)$ & --------- & -1.0905 & 0.2008 & $<0.0001$ & |-------- & -0.9949 & 0.2268 & $<0.0001$ & --------- & -1.1085 & 0.2241 & $<0.0001$ \\
\hline $3(30-34)$ & --------- & -1.1329 & 0.1937 & $<0.0001$ & |--------- & -1.0281 & 0.2174 & $<0.0001$ & |--------- & -1.0801 & 0.2131 & $<0.0001$ \\
\hline $4(35-41)$ & ---------- & -1.6176 & 0.2257 & $<0.0001$ & |--------- & -1.6113 & 0.2581 & $<0.0001$ & |-------- & -1.6788 & 0.2521 & $<0.0001$ \\
\hline BMI" & -0.0477 & -0.0342 & 0.0124 & 0.0059 & -0.1756 & -0.0277 & 0.0138 & 0.0449 & -0.1064 & -0.0285 & 0.0137 & 0.0380 \\
\hline $\begin{array}{l}\text { BMI } \\
\text { cat }^{*}\left(\mathrm{~kg} / \mathrm{m}^{2}\right)\end{array}$ & & & & & & & & & & & & \\
\hline $1(<20)$ (ref) & -0.1496 & --------- & 0.1094 & 0.1716 & -0.2432 & --------- & 0.1124 & 0.0305 & -0.1644 & --------- & 0.1106 & 0.1371 \\
\hline $2(20-25)$ & --------- & -0.1134 & 0.1963 & 0.5635 & |-------- & -0.1929 & 0.2221 & 0.3850 & |--------- & -0.2195 & 0.2204 & 0.3194 \\
\hline $3(26-30)$ & --------- & -0.0993 & 0.2265 & 0.6612 & |-------- & -0.0068 & 0.2512 & 0.9785 & |--------- & -0.0498 & 0.2519 & 0.8432 \\
\hline $4(>30)$ & --------- & -0.7272 & 0.3115 & 0.0196 & |-------- & -0.9623 & 0.3724 & 0.0098 & --------- & -0.8703 & 0.3584 & 0.0152 \\
\hline $\begin{array}{l}\text { Avg. alcohol }{ }^{\dagger} \\
\text { (per day) } \\
\text { Alcohol cat }^{\dagger}\end{array}$ & -0.1525 & -0.0517 & 0.0193 & 0.0073 & -0.2398 & -0.0596 & 0.0242 & 0.0137 & -0.0720 & -0.0630 & 0.0243 & 0.0096 \\
\hline 0 (ref) & -0.0607 & --------- & 0.1113 & 0.5852 & -0.1669 & --------- & 0.1130 & 0.1397 & -0.0289 & --------- & 0.1108 & 0.7944 \\
\hline 1 & --------- & -0.6889 & 0.2112 & 0.0011 & |--------- & -0.7111 & 0.2489 & 0.0043 & |--------- & -0.8739 & 0.2349 & 0.0002 \\
\hline 2 & --------- & -1.0223 & 0.2919 & 0.0005 & |-------- & -0.9481 & 0.3360 & 0.0048 & -------- & -1.0668 & 0.3250 & 0.0010 \\
\hline $\begin{array}{l}\text { Avg. cigarette }{ }^{\dagger} \\
\text { (per day) } \\
\text { Cigarette cat }{ }^{\dagger}\end{array}$ & -0.1636 & -0.0170 & 0.0121 & 0.1612 & -0.2448 & -0.0385 & 0.0173 & 0.0261 & -0.0704 & -0.0422 & 0.0174 & 0.0154 \\
\hline 0 (ref) & -0.1472 & --------- & 0.1056 & 0.1633 & -0.2347 & ---------- & 0.1090 & 0.0313 & -0.0527 & --------- & 0.1085 & 0.6271 \\
\hline 1 & --------- & -0.4017 & 0.1866 & 0.0313 & |--------- & -0.2422 & 0.2063 & 0.2405 & |--------- & -0.3907 & 0.2089 & 0.0615 \\
\hline 2 & --------- & -0.2714 & 0.3258 & 0.4048 & |-------- & -0.3272 & 0.4066 & 0.4209 & --------- & -0.3045 & 0.3800 & 0.4231 \\
\hline 3 & --------- & -0.3967 & 0.3395 & 0.2425 & |--------- & -1.0209 & 0.5216 & 0.0503 & -------- & -1.3539 & 0.5936 & 0.0225 \\
\hline
\end{tabular}




\begin{tabular}{|c|c|c|c|c|c|c|c|c|c|c|c|c|}
\hline $\begin{array}{l}\text { Unprotected } \\
\text { intercourse }\end{array}$ & -0.1917 & 0.3437 & 0.0597 & $<0.0001$ & -0.3002 & 0.3654 & 0.0695 & $<0.0001$ & -0.2413 & 0.3631 & 0.0699 & $<0.0001$ \\
\hline $\begin{array}{l}\text { Pregnancy } \\
\text { intention }\end{array}$ & -0.3179 & 0.6044 & 0.1535 & $<0.0001$ & -0.4378 & 0.7244 & 0.1737 & $<0.0001$ & -0.2804 & 0.5950 & 0.1724 & 0.0006 \\
\hline $\begin{array}{l}\text { Ever pregnant } \\
\text { Race }^{*}\end{array}$ & -0.1823 & 0.0312 & 0.1303 & 0.8105 & -0.2500 & -0.0060 & 0.1486 & 0.9678 & -0.0658 & -0.0680 & 0.1454 & 0.6397 \\
\hline White (ref) & -0.9977 & --------- & 0.0811 & $<0.0001$ & -0.9776 & --------- & 0.0902 & $<0.0001$ & -0.9409 & --------- & 0.0875 & $<0.0001$ \\
\hline Black & --------- & -0.6058 & 0.2428 & 0.0126 & |--------- & -0.6752 & 0.2824 & 0.0168 & |--------- & -0.7131 & 0.2803 & 0.0109 \\
\hline Other & --------- & -1.4205 & 0.3679 & $<0.0001$ & |-------- & -1.3843 & 0.4264 & 0.0012 & ------- & -1.4610 & 0.4256 & 0.0006 \\
\hline
\end{tabular}

During study 
Supplemental Table3: Multivariable model for fecundability of all pregnancies

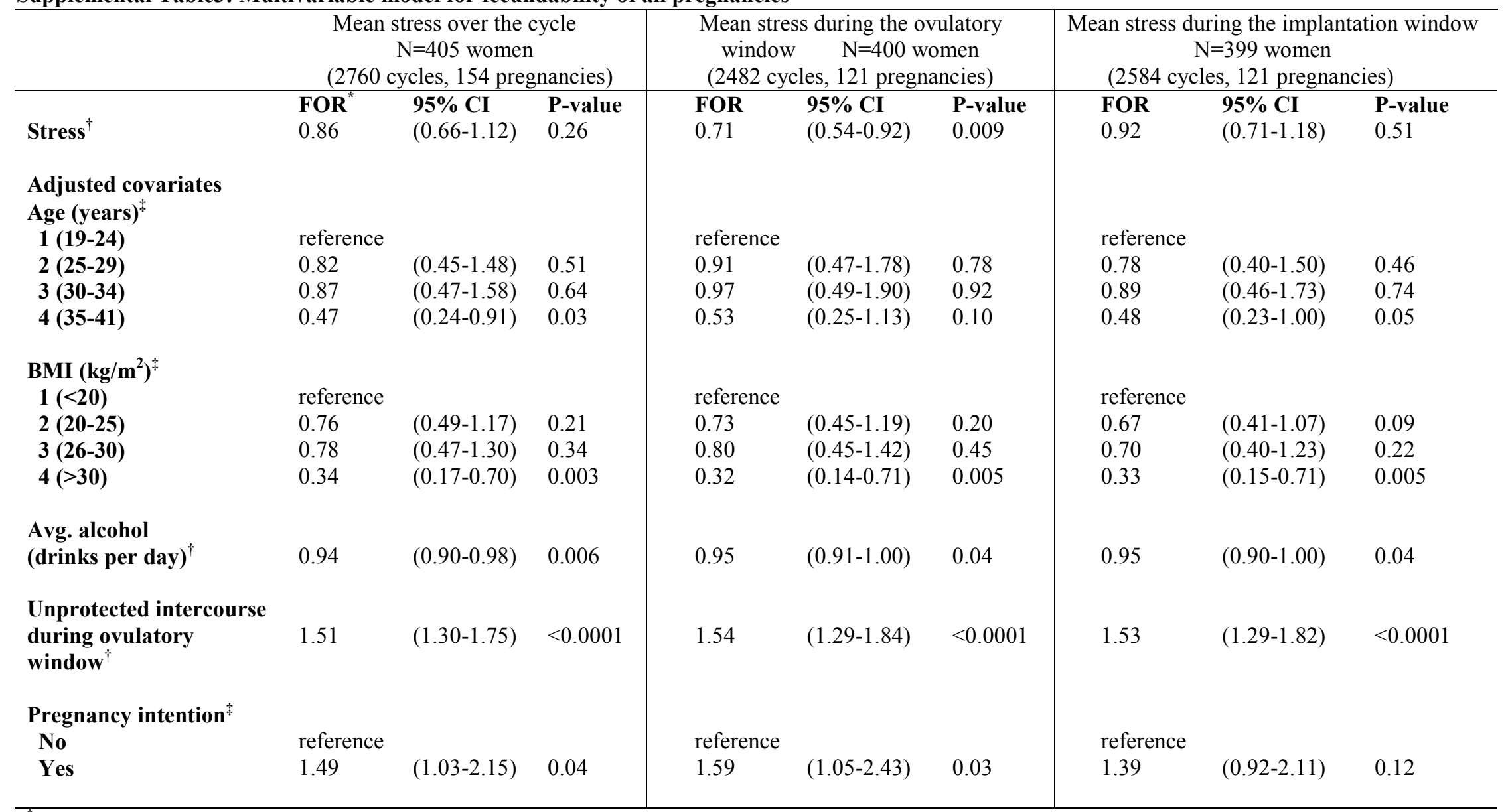

"FOR: Fecundability odds ratio

During study

${ }^{*}$ At baseline 
Supplemental Table 4: Multivariate model for fecundability for all pregnancies



Fecundability odds ratio

'During study

ॠ At baseline 
Supplemental Table 5: $\quad$ Sensitivity analysis where stress was measured for at least $90 \%$ of the cycle for all first pregnancies*

\begin{tabular}{|c|c|c|c|c|c|c|c|c|c|}
\hline & \multicolumn{3}{|c|}{$\begin{array}{l}\text { Mean stress over the cycle } \\
\mathrm{N}=370 \text { women, } 2126 \text { cycles }\end{array}$} & \multicolumn{3}{|c|}{$\begin{array}{l}\text { Mean stress during the ovulatory window } \\
\qquad N=370 \text { women, } 2116 \text { cycles }\end{array}$} & \multicolumn{3}{|c|}{$\begin{array}{l}\text { Mean stress during the implantation windov } \\
\quad \mathrm{N}=370 \text { women, } 2121 \text { cycles }\end{array}$} \\
\hline Stress & $\begin{array}{l}\mathbf{F O R}^{\dagger} \\
0.61\end{array}$ & $\begin{array}{l}\mathbf{9 5 \%} \text { CI } \\
(0.42-0.90)\end{array}$ & $\begin{array}{c}\text { P-value } \\
0.01\end{array}$ & $\begin{array}{l}\text { FOR } \\
0.66\end{array}$ & $\begin{array}{l}\mathbf{9 5 \%} \text { CI } \\
(0.48-0.92)\end{array}$ & $\begin{array}{c}\text { P-value } \\
0.01\end{array}$ & $\begin{array}{l}\text { FOR } \\
0.74\end{array}$ & $\begin{array}{l}\mathbf{9 5 \%} \text { CI } \\
(0.53-1.05)\end{array}$ & $\begin{array}{c}\text { P-value } \\
0.09\end{array}$ \\
\hline $\begin{array}{l}\text { Adjusted } \\
\text { Age (years) }\end{array}$ & & & & & & & & & \\
\hline $\begin{array}{l}1(19-24) \\
2(25-29) \\
3(30-34) \\
4(35-41)\end{array}$ & $\begin{array}{l}\text { reference } \\
0.74 \\
0.77 \\
0.55\end{array}$ & $\begin{array}{l}(0.33-1.67) \\
(0.34-1.78) \\
(0.22-1.35)\end{array}$ & $\begin{array}{l}0.47 \\
0.55 \\
0.19\end{array}$ & $\begin{array}{l}\text { reference } \\
0.79 \\
0.87 \\
0.59\end{array}$ & $\begin{array}{l}(0.34-1.85) \\
(0.37-2.06) \\
(0.23-1.50)\end{array}$ & $\begin{array}{l}0.60 \\
0.75 \\
0.26\end{array}$ & $\begin{array}{l}\text { reference } \\
0.70 \\
0.78 \\
0.53\end{array}$ & $\begin{array}{l}(0.31-1.59) \\
(0.34-1.81) \\
(0.21-1.31)\end{array}$ & $\begin{array}{l}0.39 \\
0.57 \\
0.17\end{array}$ \\
\hline $\begin{array}{l}\operatorname{BMI}\left(\mathrm{kg} / \mathrm{m}^{2}\right)^{\S} \\
1(<20)\end{array}$ & reference & & & reference & & & reference & & \\
\hline $\begin{array}{l}2(20-25) \\
3(26-30) \\
4(>30)\end{array}$ & $\begin{array}{l}0.82 \\
0.55 \\
0.2\end{array}$ & $\begin{array}{l}(0.47-1.45) \\
(0.26-1.15) \\
(0.08-0.64)\end{array}$ & $\begin{array}{l}0.50 \\
0.11 \\
0.005\end{array}$ & $\begin{array}{l}0.79 \\
0.53 \\
0.23\end{array}$ & $\begin{array}{l}(0.44-1.40) \\
(0.25-1.10) \\
(0.08-0.66)\end{array}$ & $\begin{array}{l}0.41 \\
0.09 \\
0.006\end{array}$ & $\begin{array}{l}0.76 \\
0.53 \\
0.22\end{array}$ & $\begin{array}{l}(0.43-1.35) \\
(0.25-1.12) \\
(0.08-0.64)\end{array}$ & $\begin{array}{l}0.35 \\
0.10 \\
0.005\end{array}$ \\
\hline $\begin{array}{l}\text { Avg. alcohol } \\
\text { (per day) }\end{array}$ & 0.93 & $(0.86-0.99)$ & 0.03 & 0.93 & $(0.86-0.99)$ & 0.03 & 0.93 & $(0.86-0.99)$ & 0.03 \\
\hline $\begin{array}{l}\text { Unprotected intercourse } \\
\text { during ovulatory window }\end{array}$ & 1.62 & $(1.31-2.01)$ & $<0.0001$ & 1.61 & (1.30-1.99) & $<0.0001$ & 1.58 & $(1.27-1.97)$ & $<0.0001$ \\
\hline $\begin{array}{l}\text { Pregnancy intention }^{\S} \\
\text { Yes } \\
\text { No }\end{array}$ & $\begin{array}{l}\text { reference } \\
1.14\end{array}$ & $(0.66-1.87)$ & 0.69 & $\begin{array}{l}\text { reference } \\
1.17\end{array}$ & $(0.69-1.98)$ & 0.56 & $\begin{array}{l}\text { reference } \\
1.15\end{array}$ & $(0.68-1.94)$ & 0.61 \\
\hline
\end{tabular}


Supplemental Table 6: $\quad$ Sensitivity analysis where stress was measured for at least $90 \%$ of the cycle for all pregnancies



${ }^{*}$ During study

${ }^{\dagger}$ At baseline 
Supplementary Table 7: Sensitivity analysis where stress was measured for at least $90 \%$ of the cycle for all first pregnancies* (restricted to whites only)

\begin{tabular}{|c|c|c|c|c|c|c|c|c|c|}
\hline & \multicolumn{3}{|c|}{$\begin{array}{l}\text { Mean stress over the cycle } \\
\mathrm{N}=330 \text { women, } 2312 \text { cycles }\end{array}$} & \multicolumn{3}{|c|}{$\begin{array}{l}\text { Mean stress during the ovulatory window } \\
\mathrm{N}=325 \text { women, } 2092 \text { cycles }\end{array}$} & \multicolumn{3}{|c|}{$\begin{array}{l}\text { Mean stress during the implantation windov } \\
\quad \mathrm{N}=324 \text { women, } 2175 \text { cycles }\end{array}$} \\
\hline Stress & $\begin{array}{l}\text { FOR }^{\dagger} \\
0.80\end{array}$ & $\begin{array}{l}\mathbf{9 5 \%} \text { CI } \\
(0.58-1.10)\end{array}$ & $\begin{array}{c}\text { P-value } \\
0.17\end{array}$ & $\begin{array}{l}\text { FOR } \\
0.66\end{array}$ & $\begin{array}{l}\mathbf{9 5 \%} \text { CI } \\
(0.49-0.91)\end{array}$ & $\begin{array}{l}\text { P-value } \\
0.01\end{array}$ & $\begin{array}{l}\text { FOR } \\
0.92\end{array}$ & $\begin{array}{l}\mathbf{9 5 \%} \text { CI } \\
(0.68-1.25)\end{array}$ & $\begin{array}{l}\text { P-value } \\
0.60\end{array}$ \\
\hline $\begin{array}{l}\text { Adjusted } \\
\text { Age }(\text { years) }\end{array}$ & & & & & & & & & \\
\hline $\begin{array}{l}1(19-24) \\
2(25-29) \\
3(30-34) \\
4(35-41)\end{array}$ & $\begin{array}{l}\text { reference } \\
0.70 \\
0.66 \\
0.33\end{array}$ & $\begin{array}{l}(0.35-1.40) \\
(0.33-1.33) \\
(0.15-0.72)\end{array}$ & $\begin{array}{l}0.32 \\
0.24 \\
0.005\end{array}$ & $\begin{array}{l}\text { reference } \\
0.88 \\
0.80 \\
0.49\end{array}$ & $\begin{array}{l}(0.40-1.94) \\
(0.36-1.81) \\
(0.20-1.19)\end{array}$ & $\begin{array}{l}0.75 \\
0.60 \\
0.11\end{array}$ & $\begin{array}{l}\text { reference } \\
0.63 \\
0.65 \\
0.35\end{array}$ & $\begin{array}{l}(0.30-1.34) \\
(0.30-1.39) \\
(0.15-0.81)\end{array}$ & $\begin{array}{l}0.23 \\
0.26 \\
0.01\end{array}$ \\
\hline $\begin{array}{l}\text { BMI }\left(\mathrm{kg} / \mathrm{m}^{2}\right)^{\S} \\
1(<20)\end{array}$ & reference & & & reference & & & reference & & \\
\hline $\begin{array}{l}2(20-25) \\
3(26-30) \\
4(>30)\end{array}$ & $\begin{array}{l}0.69 \\
0.62 \\
0.27\end{array}$ & $\begin{array}{l}(0.43-1.11) \\
(0.34-1.13) \\
(0.11-0.64)\end{array}$ & $\begin{array}{l}0.13 \\
0.12 \\
0.003\end{array}$ & $\begin{array}{l}0.67 \\
0.62 \\
0.18\end{array}$ & $\begin{array}{l}(0.44-1.13) \\
(0.25-1.21) \\
(0.08-0.55)\end{array}$ & $\begin{array}{l}0.13 \\
0.16 \\
0.003\end{array}$ & $\begin{array}{l}0.60 \\
0.54 \\
0.26\end{array}$ & $\begin{array}{l}(0.36-1.00) \\
(0.28-1.06) \\
(0.10-0.67)\end{array}$ & $\begin{array}{l}0.05 \\
0.07 \\
0.005\end{array}$ \\
\hline $\begin{array}{l}\text { Avg. alcohol } \\
\text { (per day) }\end{array}$ & 0.95 & $(0.90-1.00)$ & 0.03 & 0.95 & $(0.90-1.00)$ & 0.06 & 0.94 & $(0.89-1.00)$ & 0.06 \\
\hline $\begin{array}{l}\text { Unprotected intercourse } \\
\text { during ovulatory window }\end{array}$ & 1.46 & $(1.22-1.75)$ & $<0.0001$ & 1.49 & $(1.20-1.84)$ & 0.0003 & 1.43 & $(1.16-1.76)$ & 0.0007 \\
\hline $\begin{array}{l}\text { Pregnancy intention } \\
\text { Yes } \\
\text { No }\end{array}$ & $\begin{array}{l}\text { reference } \\
1.40\end{array}$ & $(0.91-1.15)$ & 0.12 & $\begin{array}{l}\text { reference } \\
1.38\end{array}$ & $(0.84-2.26)$ & 0.21 & $\begin{array}{l}\text { reference } \\
1.29\end{array}$ & $(0.79-2.09)$ & 0.31 \\
\hline
\end{tabular}

${ }^{*}$ First pregnancy in study

${ }^{\dagger}$ FOR: Fecundability odds ratio

${ }^{\ddagger}$ During study

$\S$ At baseline 
Supplemental Table 8: $\quad$ Sensitivity analysis where stress was measured for at least $90 \%$ of the cycle for all pregnancies (restricted to whites only)

\begin{tabular}{|c|c|c|c|c|c|c|c|c|c|}
\hline & $\begin{array}{l}\mathrm{Me} \\
\mathrm{N}=?\end{array}$ & $\begin{array}{l}\text { n stress over } \\
30 \text { women, } 2\end{array}$ & $\begin{array}{l}\text { e cycle } \\
1 \text { cycles }\end{array}$ & $\begin{array}{r}\text { Mean stress } \\
\mathrm{N}=32\end{array}$ & $\begin{array}{l}\text { aring the ovu } \\
\text { women, } 210\end{array}$ & $\begin{array}{l}\text { atory window } \\
\text { cycles }\end{array}$ & $\begin{array}{r}\text { Mean stress d } \\
\mathrm{N}=\end{array}$ & $\begin{array}{l}\text { ring the impl } \\
25 \text { women, } 2\end{array}$ & $\begin{array}{l}2 \text { cycles } \\
2 \text { cyindow }\end{array}$ \\
\hline & FOR ${ }^{*}$ & $95 \% \mathrm{CI}$ & P-value & FOR & 95\% CI & P-value & FOR & $95 \%$ CI & P-value \\
\hline Stress $^{\dagger}$ & 0.91 & $(0.69-1.22)$ & 0.53 & 0.71 & $(0.53-0.95)$ & 0.02 & 0.98 & $(0.74-1.30)$ & 0.90 \\
\hline Adjusted & & & & & & & & & \\
\hline Age (years) & & & & & & & & & \\
\hline $1(19-24)$ & reference & & & reference & & & reference & & \\
\hline $2(25-29)$ & 0.80 & $(0.41-1.58)$ & 0.53 & 1.08 & $(0.50-2.33)$ & 0.85 & 0.76 & $(0.36-1.57)$ & 0.45 \\
\hline $3(30-34)$ & 0.79 & $(0.40-1.55)$ & 0.50 & 1.04 & $(0.48-2.25)$ & 0.93 & 0.80 & $(0.39-1.67)$ & 0.55 \\
\hline $4(35-41)$ & 0.44 & $(0.21-0.91)$ & 0.03 & 0.65 & $(0.28-1.51)$ & 0.32 & 0.44 & $(0.20-0.99)$ & 0.05 \\
\hline 5BMI $\left(\mathrm{kg} / \mathrm{m}^{2}\right)^{+}$ & & & & & & & & & \\
\hline $1(<20)$ & reference & & & reference & & & 0.64 & $(0.39-1.05)$ & 0.08 \\
\hline $2(20-25)$ & 0.73 & $(0.46-1.16)$ & 0.19 & 0.71 & $(0.42-1.19)$ & 0.19 & 0.77 & $(0.42-1.39)$ & 0.38 \\
\hline $3(26-30)$ & 0.84 & $(0.49-1.46)$ & 0.54 & 0.87 & $(0.48-1.59)$ & 0.65 & 0.28 & $(0.12-0.70)$ & 0.006 \\
\hline $4(>30)$ & 0.28 & $(0.12-0.66)$ & 0.003 & 0.21 & $(0.08-0.59)$ & 0.003 & & & \\
\hline $\begin{array}{l}\text { Avg. alcohol }{ }^{\dagger} \\
\text { (drinks per day) }\end{array}$ & 0.96 & $(0.91-1.00)$ & 0.04 & 0.96 & $(0.91-1.00)$ & 0.09 & 0.95 & $(0.91-1.00)$ & 0.08 \\
\hline $\begin{array}{l}\text { Unprotected intercourse } \\
\text { in ovulatory window }{ }^{\dagger}\end{array}$ & 1.48 & $(1.25-1.75)$ & $<0.0001$ & 1.52 & $(1.24-1.86)$ & $<0.0001$ & 1.47 & $(1.21-1.79)$ & $<0.0001$ \\
\hline Pregnancy intention & & & & & & & & & \\
\hline No & reference & & & reference & & & reference & & \\
\hline Yes & 1.54 & $(1.03-2.30)$ & 0.04 & 1.50 & $(0.90-2.37)$ & 0.09 & 1.41 & $(0.90-2.21)$ & 0.14 \\
\hline
\end{tabular}

${ }^{*}$ Fecundability odds ratio

'During study

At baseline 
Supplemental Table 9: Unadjusted and adjusted estimates for spontaneous abortion for all first pregnancies"

\begin{tabular}{|c|c|c|c|c|c|c|c|c|c|c|c|c|}
\hline & \multicolumn{4}{|c|}{$\begin{array}{l}\text { Mean stress over the cycle } \\
\mathrm{N}=159 \text { pregnancies }(40 \mathrm{SA})\end{array}$} & \multicolumn{4}{|c|}{$\begin{array}{l}\text { Mean stress during the ovulatory window } \\
\qquad \mathrm{N}=122 \text { pregnancies ( } 35 \mathrm{SA})\end{array}$} & \multicolumn{4}{|c|}{$\begin{array}{l}\text { Mean stress during the implantation window } \\
\qquad \mathrm{N}=121 \text { pregnancies ( } 37 \mathrm{SA})\end{array}$} \\
\hline & $\begin{array}{l}\text { Stress } \\
\text { Estimate }\end{array}$ & $\begin{array}{l}\text { Covariate } \\
\text { Estimate }\end{array}$ & $\begin{array}{l}\text { Standard } \\
\text { Error }\end{array}$ & P-value & $\begin{array}{l}\text { Stress } \\
\text { Estimate }\end{array}$ & $\begin{array}{l}\text { Covariate } \\
\text { Estimate }\end{array}$ & $\begin{array}{l}\text { Standard } \\
\text { Error }\end{array}$ & P-value & $\begin{array}{l}\text { Stress } \\
\text { Estimate }\end{array}$ & $\begin{array}{l}\text { Covariate } \\
\text { Estimate }\end{array}$ & $\begin{array}{l}\text { Standard } \\
\text { Error }\end{array}$ & P-value \\
\hline Unadjusted & 0.0501 & & 0.3200 & 0.8755 & -0.3309 & & 0.2881 & 0.2507 & -0.5927 & & 0.1137 & 0.6371 \\
\hline \multicolumn{13}{|l|}{$\begin{array}{l}\text { Adjusted } \\
\text { (one at a time) }\end{array}$} \\
\hline $\operatorname{Age}^{\dagger}$ & 0.0085 & 0.0600 & 0.0460 & 0.1918 & -0.4022 & 0.0765 & 0.0515 & 0.1373 & -0.1363 & 0.0649 & 0.0502 & 0.1954 \\
\hline \multicolumn{13}{|l|}{$\begin{array}{l}\text { Age cat }^{\dagger} \\
\text { (years) }\end{array}$} \\
\hline 1 (19-24) (ref) & 0.1130 & ----------- & 0.3397 & 0.7395 & -0.3614 & --------- & 0.3050 & 0.2361 & -0.1139 & --------- & 0.2594 & 0.6607 \\
\hline $2(25-29)$ & --------- & -0.8522 & 0.7880 & 0.2795 & --------- & -0.9868 & 0.8474 & 0.2442 & |-------- & -1.2664 & 0.8714 & 0.1461 \\
\hline $3(30-34)$ & --------- & 0.1673 & 0.7328 & 0.8194 & --------- & -0.1316 & 0.7974 & 0.8689 & --------- & -0.3272 & 0.8193 & 0.6896 \\
\hline $4(35-41)$ & --------- & 0.1868 & 0.8015 & 0.8157 & --------- & 0.4317 & 0.8735 & 0.6211 & --------- & -0.0356 & 0.8862 & 0.9679 \\
\hline $\mathbf{B M I}^{\dagger}$ & 0.0460 & -0.0106 & 0.0461 & 0.8184 & -0.3594 & -0.0504 & 0.0517 & 0.3297 & -0.1179 & -0.0208 & 0.0478 & 0.6634 \\
\hline \multicolumn{13}{|l|}{$\begin{array}{l}\text { BMI cat } \\
\left(\mathrm{kg} / \mathrm{m}^{2}\right)\end{array}$} \\
\hline $1(<20)$ (ref) & 0.0678 & --------- & 0.3319 & 0.8381 & -0.3651 & --------- & 0.3006 & 0.2245 & -0.0981 & --------- & 0.2512 & 0.6963 \\
\hline $2(20-25)$ & --------- & -0.4039 & 0.4955 & 0.4150 & --------- & -0.5051 & 0.5278 & 0.3386 & --------- & -0.3070 & 0.5191 & 0.5542 \\
\hline $3(26-30)$ & --------- & 0.5524 & 0.5593 & 0.3233 & |--------- & 0.4214 & 0.5957 & 0.4794 & |--------- & 0.6729 & 0.5689 & 0.2612 \\
\hline $4(>30)$ & --------- & -0.6420 & 0.8792 & 0.4653 & --------- & -1.5006 & 1.1541 & 0.1935 & --------- & -0.6308 & 0.8998 & 0.4833 \\
\hline $\begin{array}{l}\text { Avg. alcohol } \\
\text { (per day) }^{*}\end{array}$ & 0.0596 & 0.0502 & 0.0424 & 0.2364 & -0.3234 & 0.0364 & 0.0436 & 0.4044 & -0.1453 & 0.0403 & 0.0435 & 0.3542 \\
\hline \multicolumn{13}{|l|}{ Alcohol cat } \\
\hline 0 (ref) & 0.0635 & --------- & 0.3350 & 0.8496 & -0.3293 & --------- & 0.3020 & 0.2756 & -0.1466 & ---------- & 0.2538 & 0.5636 \\
\hline 1 & --------- & 0.3715 & 0.5932 & 0.5311 & |--------- & 0.7984 & 0.6793 & 0.2399 & |-------- & 0.9601 & 0.6723 & 0.1533 \\
\hline 2 & --------- & 1.8551 & 0.7449 & 0.0128 & --------- & 1.8289 & 0.8432 & 0.0301 & --------- & 1.9106 & 0.8397 & 0.0229 \\
\hline $\begin{array}{l}\text { Avg. cigarette } \\
\text { (per day) }\end{array}$ & 0.0380 & 0.0117 & 0.0285 & 0.6807 & -0.3268 & 0.0186 & 0.0392 & 0.6361 & -0.1181 & 0.0179 & 0.0400 & 0.6556 \\
\hline \multicolumn{13}{|l|}{ Cigarette cat } \\
\hline 0 (ref) & 0.6477 & --------- & 0.3270 & 0.7605 & -0.3104 & --------- & 0.2895 & 0.2838 & -0.1353 & --------- & 0.2408 & 0.5740 \\
\hline 1 & ---------- & 0.6477 & 0.4287 & 0.1308 & ---------- & 0.5719 & 0.4626 & 0.2164 & --------- & 0.6374 & 0.4660 & 0.1714 \\
\hline 2 & --------- & -1.0094 & 1.0792 & 0.3496 & |--------- & -0.7671 & 1.1101 & 0.4896 & |-------- & -1.0096 & 1.0961 & 0.3570 \\
\hline 3 & --------- & 0.0951 & 0.8480 & 0.9107 & --------- & 0.2919 & 1.2508 & 0.8155 & -------- & 0.9713 & 1.4373 & 0.4992 \\
\hline $\begin{array}{l}\text { Pregnancy } \\
\text { intention }\end{array}$ & -0.1377 & -0.9568 & 0.4244 & 0.0242 & -0.3801 & -0.8284 & 0.4491 & 0.0651 & -0.1275 & -0.8413 & 0.4444 & 0.0583 \\
\hline
\end{tabular}




\begin{tabular}{|c|c|c|c|c|c|c|c|c|c|c|c|c|}
\hline $\begin{array}{l}\text { Ever pregnant } \\
\text { Race }^{\dagger}\end{array}$ & 0.0723 & -0.1586 & 0.3016 & 0.5990 & -0.3159 & -0.1066 & 0.3148 & 0.7348 & -0.1056 & -0.1700 & 0.3152 & 0.5897 \\
\hline White (ref) & -0.0628 & --------- & 0.3298 & 0.8489 & -0.3684 & --------- & 0.2969 & 0.2148 & -0.2011 & --------- & 0.2523 & 0.4253 \\
\hline Black & --------- & -1.8644 & 1.0531 & 0.0767 & --------- & -1.7890 & 1.0663 & 0.0934 & |--------- & -1.9197 & 1.0697 & 0.0727 \\
\hline Other & --------- & -1.0260 & 1.0868 & 0.3451 & --------- & -0.8537 & 1.1232 & 0.4472 & |-------- & -0.6873 & 1.1416 & 0.5471 \\
\hline
\end{tabular}

*First pregnancy in study

At baseline

‡ During study 
Supplemental Table 10: Unadjusted and adjusted estimates for spontaneous abortion for all pregnancies

\begin{tabular}{|c|c|c|c|c|c|c|c|c|c|c|c|c|}
\hline & \multicolumn{4}{|c|}{$\begin{array}{l}\text { Mean stress over the cycle } \\
\mathrm{N}=178 \text { pregnancies }(50 \mathrm{SA})\end{array}$} & \multicolumn{4}{|c|}{$\begin{array}{l}\text { Mean stress during the ovulatory window } \\
\qquad \mathrm{N}=139 \text { pregnancies ( } 45 \mathrm{SA})\end{array}$} & \multicolumn{4}{|c|}{$\begin{array}{l}\text { Mean stress during the implantation window } \\
\quad \mathrm{N}=138 \text { pregnancies (47 SA) }\end{array}$} \\
\hline & $\begin{array}{l}\text { Stress } \\
\text { Estimate }\end{array}$ & $\begin{array}{l}\text { Covariate } \\
\text { Estimate }\end{array}$ & $\begin{array}{l}\text { Standard } \\
\text { Error }\end{array}$ & P-value & $\begin{array}{l}\text { Stress } \\
\text { Estimate }\end{array}$ & $\begin{array}{l}\text { Covariate } \\
\text { Estimate }\end{array}$ & $\begin{array}{l}\text { Standard } \\
\text { Error }\end{array}$ & P-value & $\begin{array}{l}\text { Stress } \\
\text { Estimate }\end{array}$ & $\begin{array}{l}\text { Covariate } \\
\text { Estimate }\end{array}$ & $\begin{array}{l}\text { Standard } \\
\text { Error }\end{array}$ & P-value \\
\hline Unadjusted & 0.0162 & & 0.3022 & 0.9572 & -0.3027 & & 0.2696 & 0.2616 & -0.0793 & & 0.2267 & 0.7266 \\
\hline $\begin{array}{l}\text { Adjusted } \\
\text { (one at a time) }\end{array}$ & & & & & & & & & & & & \\
\hline $\begin{array}{l}\text { Age } \\
\text { Age cat } \\
\text { (years) }\end{array}$ & -0.0513 & 0.0714 & 0.0410 & 0.0818 & -0.4153 & 0.0978 & 0.0461 & 0.0340 & -0.1163 & 0.0838 & 0.0450 & 0.0623 \\
\hline $1(19-24)$ (ref) & 0.0281 & --------- & 0.3207 & 0.9303 & -0.3827 & --------- & 0.2887 & 0.1849 & -0.1047 & --------- & 0.2439 & 0.6677 \\
\hline $2(25-29)$ & --------- & -0.4148 & 0.7517 & 0.5810 & --------- & -0.4450 & 0.7915 & 0.5740 & -------- & -0.6719 & 0.8009 & 0.4015 \\
\hline $3(30-34)$ & --------- & 0.5878 & 0.7074 & 0.4060 & --------- & 0.4279 & 0.7495 & 0.5681 & |-------- & 0.2675 & 0.7579 & 0.7241 \\
\hline $4(35-41)$ & -------- & 0.5861 & 0.7616 & 0.4416 & -------- & 1.0040 & 0.8202 & 0.2209 & |-------- & 0.6455 & 0.8165 & 0.4292 \\
\hline BMI* & 0.0172 & 0.0061 & 0.0413 & 0.8819 & -0.3109 & -0.0216 & 0.0450 & 0.6312 & -0.0793 & -0.0001 & 0.0429 & 0.9977 \\
\hline $\begin{array}{l}\text { BMI cat } \\
\left(\mathrm{kg} / \mathrm{m}^{2}\right)\end{array}$ & & & & & & & & & & & & \\
\hline $1(<20)$ & 0.0541 & --------- & 0.3147 & 0.8635 & -0.3301 & --------- & 0.2824 & 0.2425 & -0.0393 & --------- & 0.2364 & 0.8679 \\
\hline $2(20-25)$ & --------- & -0.4716 & 0.4588 & 0.3041 & -------- & -0.5185 & 0.4864 & 0.2865 & |------- & -0.3516 & 0.4804 & 0.4642 \\
\hline $3(26-30)$ & --------- & 0.5685 & 0.4992 & 0.2548 & --------- & 0.5201 & 0.5288 & 0.3235 & |--------- & 0.7084 & 0.5310 & 0.1822 \\
\hline $4(>30)$ & --------- & -0.3737 & 0.7597 & 0.6228 & --------- & -0.8702 & 0.8895 & 0.3279 & |--------- & -0.3323 & 0.7827 & 0.6712 \\
\hline $\begin{array}{l}\text { Avg. alcohol }{ }^{\dagger} \\
\text { (per day) }\end{array}$ & 0.0217 & 0.0638 & 0.0393 & 0.1047 & -0.2900 & 0.0558 & 0.0421 & 0.1846 & -0.1214 & 0.0590 & 0.0420 & 0.1607 \\
\hline Alcohol cat ${ }^{\dagger}$ & & & & & & & & & & & & \\
\hline 0 (ref) & 0.0407 & --------- & 0.3168 & 0.8979 & -0.2679 & --------- & 0.2814 & 0.3412 & -0.1104 & --------- & 0.2382 & 0.6431 \\
\hline 1 & --------- & 0.3290 & 0.5398 & 0.5422 & -------- & 0.6814 & 0.6006 & 0.2566 & |-------- & 0.8394 & 0.5963 & 0.1592 \\
\hline 2 & ---------- & 1.8374 & 0.6757 & 0.0065 & |-------- & 1.7844 & 0.7446 & 0.0166 & |--------- & 1.8796 & 0.7424 & 0.0113 \\
\hline $\begin{array}{l}\text { Avg. cigarette } \\
\text { (per day) }\end{array}$ & 0.0128 & 0.0034 & 0.0283 & 0.9054 & -0.3012 & 0.0076 & 0.0388 & 0.8453 & -0.0811 & 0.0070 & 0.0397 & 0.8599 \\
\hline Cigarette cat ${ }^{\dagger}$ & & & & & & & & & & & & \\
\hline 0 (ref) & 0.0705 & --------- & 0.3080 & 0.8190 & -0.2832 & --------- & 0.2707 & 0.2953 & -0.0892 & --------- & 0.2264 & 0.6938 \\
\hline 1 & --------- & 0.5586 & 0.3893 & 0.1513 & -------- & 0.4365 & 0.4160 & 0.2940 & |-------- & 0.4942 & 0.4184 & 0.2375 \\
\hline 2 & --------- & -1.1828 & 1.0746 & 0.2710 & --------- & -0.9758 & 1.1043 & 0.3769 & |--------- & -1.2018 & 1.0911 & 0.2707 \\
\hline 3 & --------- & -0.0806 & 0.8424 & 0.9238 & |-------- & 0.0859 & 1.2458 & 0.9450 & |-------- & 0.7665 & 1.4330 & 0.5927 \\
\hline $\begin{array}{l}\text { Pregnancy } \\
\text { intention }\end{array}$ & -0.2065 & -1.2150 & 0.3984 & 0.0023 & -0.3347 & -1.1445 & 0.4179 & 0.0062 & -0.1045 & -1.1386 & 0.4155 & 0.0061 \\
\hline
\end{tabular}




\begin{tabular}{|c|c|c|c|c|c|c|c|c|c|c|c|c|}
\hline $\begin{array}{l}\text { Ever pregnant } \\
\text { Race }\end{array}$ & 0.0405 & -0.1759 & 0.2822 & 0.5332 & -0.2864 & -0.1190 & 0.2936 & 0.6853 & -0.0713 & -0.1732 & 0.2951 & 0.5572 \\
\hline White (ref) & -0.0966 & --------- & 0.3124 & 0.7572 & -0.3334 & --------- & 0.2792 & 0.2324 & -0.1574 & --------- & 0.2369 & 0.5064 \\
\hline Black & --------- & -2.0174 & 1.0494 & 0.0546 & -------- & -1.9447 & 1.0614 & 0.0669 & -------- & -2.0459 & 1.0614 & 0.0545 \\
\hline Other & -------- & -1.1726 & 1.0838 & 0.2793 & -------- & -1.0142 & 1.1182 & 0.3644 & |-------- & -0.8415 & 1.1370 & 0.4593 \\
\hline
\end{tabular}

At baseline

${ }^{\dagger}$ During study 
Supplemental Table 11: Multivariable models for spontaneous abortion for all pregnancies

\begin{tabular}{|c|c|c|c|c|c|c|c|c|c|}
\hline & \multicolumn{3}{|c|}{$\begin{array}{l}\text { Mean stress over the cycle } \\
\mathrm{N}=158 \text { pregnancies }(48 \mathrm{SA})\end{array}$} & \multicolumn{3}{|c|}{$\begin{array}{l}\text { Mean stress during the ovulatory window } \\
\mathrm{N}=122 \text { pregnancies ( } 43 \mathrm{SA})\end{array}$} & \multicolumn{3}{|c|}{$\begin{array}{l}\text { Mean stress during the implantation window } \\
\qquad \mathrm{N}=123 \text { pregnancies ( } 45 \mathrm{SA})\end{array}$} \\
\hline & OR & $95 \%$ CI & P-value & OR & $95 \%$ CI & P-value & OR & $95 \%$ CI & P-value \\
\hline Stress ${ }^{*}$ & 0.76 & $(0.39-1.49)$ & 0.43 & 0.63 & $(0.34-1.17)$ & 0.15 & 0.82 & $(0.48-1.39)$ & 0.46 \\
\hline $\begin{array}{l}\text { Adjusted covariates } \\
\text { Age (years) }\end{array}$ & 1.10 & $(1.01-1.20)$ & 0.04 & 1.13 & $(1.02-1.25)$ & 0.02 & 1.11 & $(1.01-1.23)$ & 0.03 \\
\hline $\begin{array}{l}\text { Avg. alcohol } \\
\text { (drinks per day) }\end{array}$ & 1.06 & $(0.98-1.15)$ & 0.16 & 1.03 & $(0.94-1.13)$ & 0.50 & 1.04 & $(0.95-1.14)$ & 0.38 \\
\hline $\begin{array}{l}\text { Pregnancy } \\
\text { intention }^{\dagger} \\
\text { No } \\
\text { Yes }\end{array}$ & $\begin{array}{l}\text { reference } \\
0.31\end{array}$ & $(0.14-0.70)$ & 0.005 & $\begin{array}{l}\text { reference } \\
0.31\end{array}$ & $(0.13-0.72)$ & 0.01 & $\begin{array}{l}\text { reference } \\
0.31\end{array}$ & $(0.13-0.72)$ & 0.006 \\
\hline
\end{tabular}

"During study

${ }^{\dagger}$ At baseline 
Supplemental Table 12: Multivariate model for spontaneous abortion for all pregnancies

\begin{tabular}{|c|c|c|c|}
\hline \multicolumn{4}{|c|}{$\begin{array}{l}\text { Mean stress during cycle relative to woman average stress } \\
\qquad \mathrm{N}=178 \text { pregnancies ( } 50 \mathrm{SA})\end{array}$} \\
\hline Stress ${ }^{*}$ & $\begin{array}{l}\mathbf{O R} \\
2.21\end{array}$ & $\begin{array}{l}\mathbf{9 5 \%} \text { CI } \\
(1.09-4.48)\end{array}$ & $\begin{array}{l}\text { P-value } \\
0.03\end{array}$ \\
\hline \multicolumn{4}{|c|}{ Adjusted covariates } \\
\hline \multicolumn{4}{|c|}{$\begin{array}{l}\text { Alcohol cat* } \\
\text { (per day) }\end{array}$} \\
\hline $\mathbf{0}$ & reference & & \\
\hline 1 & 1.26 & $(0.43-3.71)$ & 0.67 \\
\hline 2 & 6.63 & $(1.67-26.3)$ & 0.007 \\
\hline
\end{tabular}




\title{
CURRICULUM VITAE
}

\author{
SekufeAkhter \\ 800 S.4th St. Apt 705 Louisville KY, 40203 \\ 606-434-5539 \\ S0akht03@louisville.edu
}

\section{EDUCATION}

UNIVERSITY OF LOUISVILLE, Louisville, KY

School of Public Health \& Information Sciences

- Master of Science in Epidemiology

August 2014

Director ${ }^{\text {e }}$ S Scholarship (1-2 years)

School of Arts \& Sciences

- Bachelor of Science in Psychology and Chemistry May 2012 - Cum Laude

Trustee ees Scholarship (4 years)

KEES Scholarship (4 years)

\section{MEDICAL FIELD OBSERVATIONS}

Appalachian Regional Hospital, Hazard KY

Cancer Clinic, Dr. Hassan H. Ghazal $\quad$ 40+ hours

Operating Room \& ICU, Dr. M.S Chaudhary 20+ hours

$\begin{array}{ll}\text { Pulmonary Unit \& ICU, Dr. R. Alam 20+ hours } & \text { 20 }\end{array}$

$\begin{array}{ll}\text { Pediatric Unit, Dr. Kanta Arya } & 10+\text { hours }\end{array}$

Emergency Room, Dr. S. Singh $\quad 10+$ hours

Internal Medicine Unit \& Dialysis, Dr. S. Schmidt $\quad$ 10+ hours 


\section{WORK}

UofL Supplemental Instructor - REACH

Recover Unit Assistant

UofL Healthcare

Plasma biomarkers of neuro- and nephrotoxicity.

proteome alterations during developmental $\mathrm{Pb}$ exposure.

UofL Department of Environmental and

Occupational Health Sciences

Nanny

\section{COMMUNITY SERVICE}

One-Day Surgery Unit,

University of Louisville Hospital

Home of the Innocents, Louisville KY

Various Benefit 5K Races

Project Downtown

Child and Adolescent Tutor

Louisville Free Public Library

Kitty Comfort \&Trainer, KY Humane Society

Meals to Heal, Louisville Salvation Army

Children's Daycare

Alice Lloyd College Child Development Center

\section{LEADERSHIP}

Phi Delta Epsilon, Vice President of Finance

Pennies for Peace, Secretary

Vietnamese Student Association
January 2014 - present June 2012 - present

January 2012 -April 2013

January 2010 - May 2012

August 2010-present

August 2012-present

August 2012-present

October 2011- October 2012

January 2011-January 2012

August 2011- January 2012

March 2009

August 2006-May 2008

2011- October 2012

October 2010 - May 2012

2010 - May 2012 
Muslim Student Association, Treasurer

ICEK Leader, Instructor \& Student

RESEARCH

Masteres Thesis

Working Memory \& Attention Mechanisms in Skill Learning

Independent Undergraduate Research in Organic Chemistry

Areas of Capacitance of Learning Neural Areas

August 2009-February 2010

\section{PRESENTATIONS}

Master's Defense

POINT: Pregnancy Outcome, Infection \& Nutritional Tracking Study

UGR Symposium Poster on Working Memory Research

Strategy Bias Constrains Insight in Problem-Solving

\section{ACADEMIC PAPERS}

The Impact of Preconception Maternal Stress on Fecundability and Pregnancy Outcomes

Study Design for POINT: Pregnancy Outcome, Infection \& Nutritional Tracking Study

A New Biomarker for Estimation of Glomerular Filtration Rate

Synthesis of Phosphines via $\mathrm{NaOH} \& \mathrm{H}_{2} \mathrm{O}_{2}$ method \& synthesis

of phosphine oxides via chlorination \& urea
July 2014

2008- December 2012

2001 - August 2012

July 2013- present

August 2011- May 2013

May 2011- July 2011

April 2013

May 2012

July 2014

April 2013

December 2012

August 2011

\section{SKILLS}

Computer: $\quad$ Proficient in SAS, C++ Programming, SPSS, \& Microsoft Office

Essentials

Languages: Bangla, Urdu, Hindi, Korean (currently learning) 